\title{
Boronic Acid: A Bio-Inspired Strategy to Increase the Sensitivity and Selectivity of Fluorescent NADH Probe
}

Lu Wang, ${ }^{1}$ Jingye Zhang, ${ }^{2}$ Beomsue Kim, ${ }^{3}$ Juanjuan Peng, ${ }^{3}$ Stuart N. Berry, Yong Ni, ${ }^{3}$ Dongdong Su, ${ }^{3}$ Jungyeol Lee, ${ }^{1}$ Lin Yuan, ${ }^{4}$ Young-Tae Chang* ${ }^{1,3}$

${ }^{1}$ Department of Chemistry and Medicinal Chemistry Programme, National University of Singapore, Singapore 117543

${ }^{2}$ Key Laboratory of Smart Drug Delivery, Ministry of Education, School of Pharmacy, Fudan University, Shanghai 201203, PR China

${ }^{3}$ Laboratory of Bioimaging Probe Development, Singapore Bioimaging Consortium, Singapore 117543

${ }^{4}$ State Key Laboratory of Chemo/Biosensing and Chemometrics, College of Chemistry and Chemical Engineering, Hunan University, Changsha 410082, PR China 


\section{Supporting Information}

\section{Table of content}

$\begin{array}{lr}\text { 1. Supplemental Figures and Tables } & \text { S3-19 }\end{array}$

2. Materials and General Experimental Methods. S19

$\begin{array}{ll}\text { 3. Synthesis and Characterization } & \text { S20-21 }\end{array}$

$\begin{array}{lr}\text { 4. Photospectroscopic Studies } & \text { S21-22 }\end{array}$

5. In Vitro Fluorescence Microscopic Studies $\quad$ S22-23

$\begin{array}{lrr}\text { 6. Supplemental Spectra } & \text { S24-32 }\end{array}$

$\begin{array}{lll}\text { 7. } & \text { Reference } & \text { S33 }\end{array}$ 


\section{Supplemental Figures and Tables}

Table S1. Photophysical parameters of fluorophores.

\begin{tabular}{cccccc}
\hline Dye & $\lambda_{\max \text { ex }}(\mathrm{nm})^{a}$ & $\varepsilon_{\max }\left(10^{4} \mathrm{~cm}^{-1} \mathrm{~mol}^{-1}\right)^{b}$ & $\Phi\left(10^{-2}\right)^{c}$ & $\lambda_{\max \text { em }}(\mathrm{nm})^{d}$ & $\begin{array}{c}\text { Rate constant k }\left(\mathrm{M}^{-1}\right. \\
\left.\mathrm{min}^{-1}\right)^{j}\end{array}$ \\
\hline BA-Resa & $535^{f} / 535^{g} / 535^{h}$ & $1.22^{f} / 1.26^{g} / 1.82^{h}$ & $0.36^{f} / 0.41^{g} / 0.4^{h}$ & $625^{f} / 625^{g} / 620^{h}$ & $4.63^{f} / 54.3^{g} / 14.4^{h}$ \\
Con-Resa & $530^{h}$ & $1.78^{h}$ & $0.40^{h}$ & $615^{h}$ & $3.36^{h}$ \\
BA-Resa-P & $485^{g}$ & $1.32^{g}$ & $1.6^{g}$ & $575^{g}$ & n.d. $^{g}$ \\
Resazurin & $600^{g}$ & $4.70^{g}$ & $11^{g}$ & $635^{g}$ & $1.33^{g}$ \\
RA-Resa & $535^{f}$ & $1.2^{f}$ & $0.37^{f}$ & $625^{f}$ & $38.6^{f}$ \\
\hline
\end{tabular}

All the photophysical parameters were measured in DMSO/PBS buffer $\left({ }^{f} 1 / 99, \mathrm{pH} 7.4 ;{ }^{g} 1 / 99 \mathrm{pH} 9.5 ;{ }^{h} 50 / 50, \mathrm{pH}\right.$ 9.5). ${ }^{a}$ Maximum absorbance wavelength of fluorophores. ${ }^{b}$ The molar extinction coefficients at $\lambda_{\max }{ }^{c}$ Fluorescence quantum yield. Resazurin in PBS buffer ( $\mathrm{pH}$ 9.5) was chosen as the reference fluorophore. ${ }^{1} d$ Maximum emission wavelength. ${ }^{j}$ The rate constant refer to reported methods. ${ }^{2}$

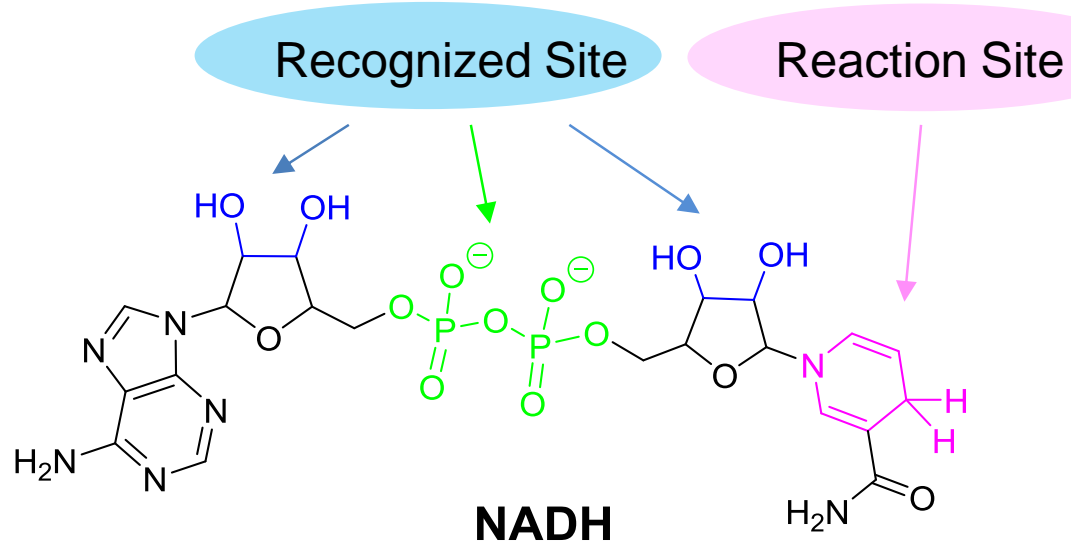

Figure S1. The structure of NADH. 


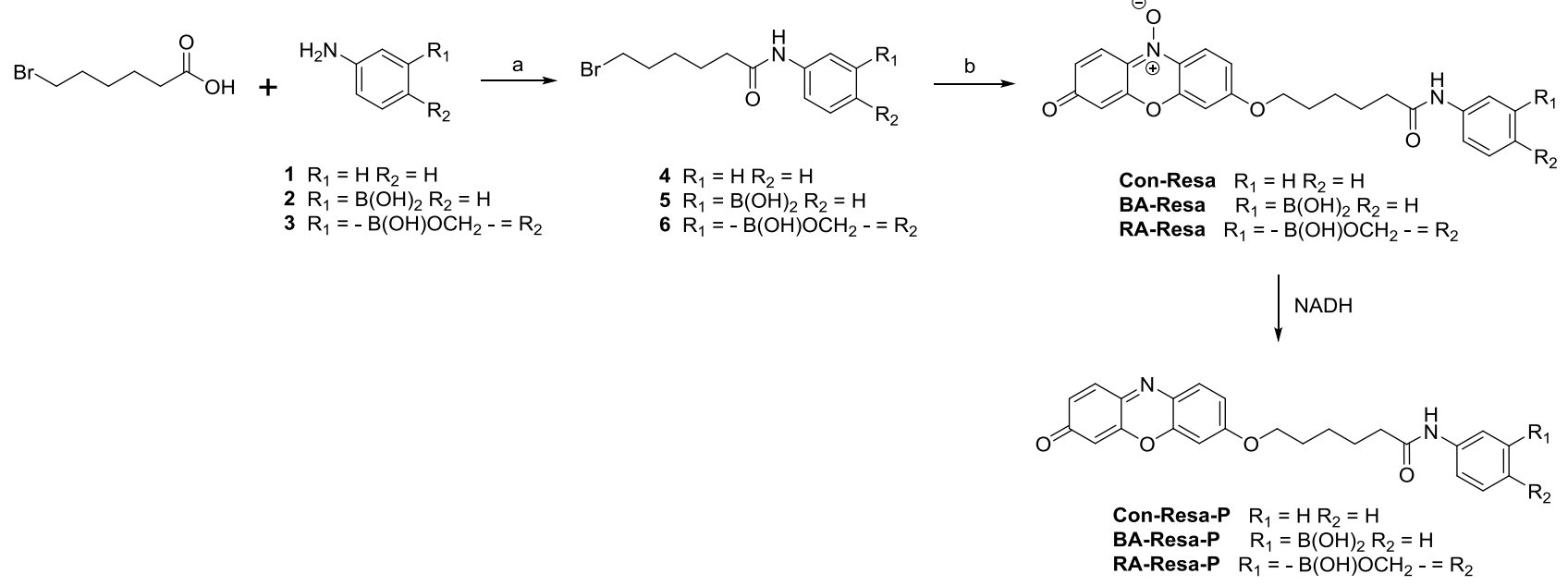

Scheme S1. The synthesis of NADH probe (BA-Resa and RA-Resa) and control probe (Con-Resa). Synthetic conditions: a) EDC, $\mathrm{HOBt}$, DCM, r.t. b) Resazurin, $\mathrm{K}_{2} \mathrm{CO}_{3}$, DMF, $75^{\circ} \mathrm{C}$.

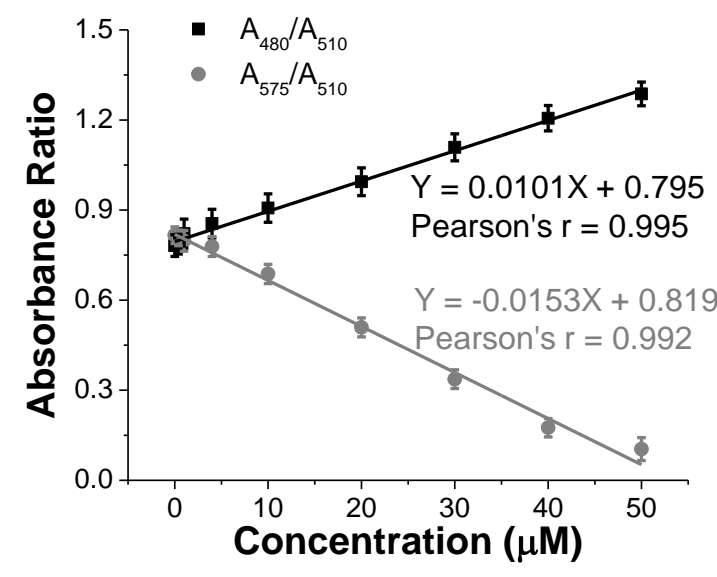

Figure S2. Plot of the UV-Vis absorbance ratio $\left(\mathrm{A}_{485} / \mathrm{A}_{510}\right.$ and $\left.\mathrm{A}_{575} / \mathrm{A}_{510}\right)$ in the NADH titration. Measurement condition: [BA-Resa] $=10 \mu \mathrm{M},[\mathrm{NADH}]=0-50 \mu \mathrm{M}, 10 \mathrm{mM}$ phosphate buffer saline $(\mathrm{pH}$ 9.5) solution, DMSO/PBS (1/99), $37{ }^{\circ} \mathrm{C}$, and incubation time: $20 \mathrm{~min}$. Results are expressed as mean \pm standard deviation of three independent experiments. 


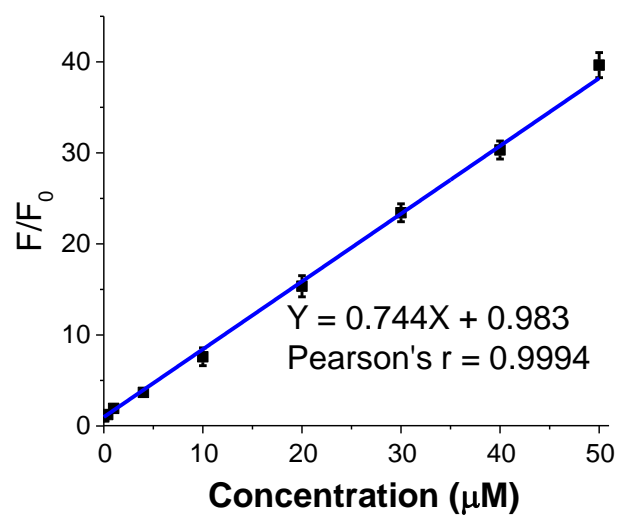

Figure S3. Curve-fitting analysis of the fluorescence intensity at $575 \mathrm{~nm}$ in the $\mathrm{NADH}$ titration. $\mathrm{F} / \mathrm{F}_{0}$ represents the fluorescence intensity ratio $(575 \mathrm{~nm})$ and $F_{0}$ is the initial fluorescence intensity $(575 \mathrm{~nm})$ of BA-Resa in the absence of NADH. Measurement condition: $[$ BA-Resa] $=10 \mu \mathrm{M},[\mathrm{NADH}]=0-50 \mu \mathrm{M}, 10 \mathrm{mM}$ phosphate buffer saline ( $\mathrm{pH}$ 9.5) solution, DMSO/PBS (1/99), $\lambda \mathrm{ex}=480 \mathrm{~nm}, 37^{\circ} \mathrm{C}$, and incubation time: $20 \mathrm{~min}$. Results are expressed as mean \pm standard deviation of three independent experiments.

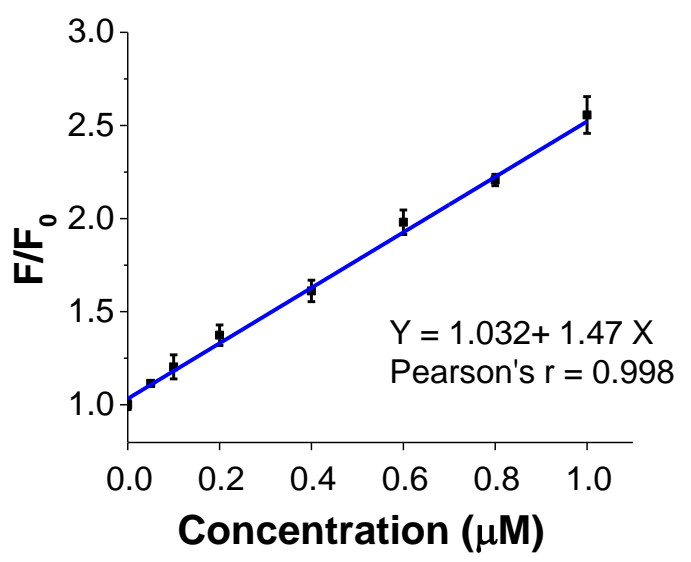

Figure S4. Curve-fitting analysis of the fluorescence intensity at $575 \mathrm{~nm}$ in the NADH titration $(0-1 \mu \mathrm{M}) . \mathrm{F} / \mathrm{F}_{0}$ represents the fluorescence intensity ratio $(575 \mathrm{~nm})$ and $\mathrm{F}_{0}$ is the initial fluorescence intensity $(575 \mathrm{~nm})$ of BAResa in the absence of NADH. Measurement condition: [BA-Resa] $=2 \mu \mathrm{M}, 10 \mathrm{mM}$ phosphate buffer saline $(\mathrm{pH}$ 9.5) solution, DMSO/PBS (1/99), $\lambda \mathrm{ex}=480 \mathrm{~nm}, 37^{\circ} \mathrm{C}$, and incubation time: $20 \mathrm{~min}$. Results are expressed as mean \pm standard deviation of three independent experiments. 

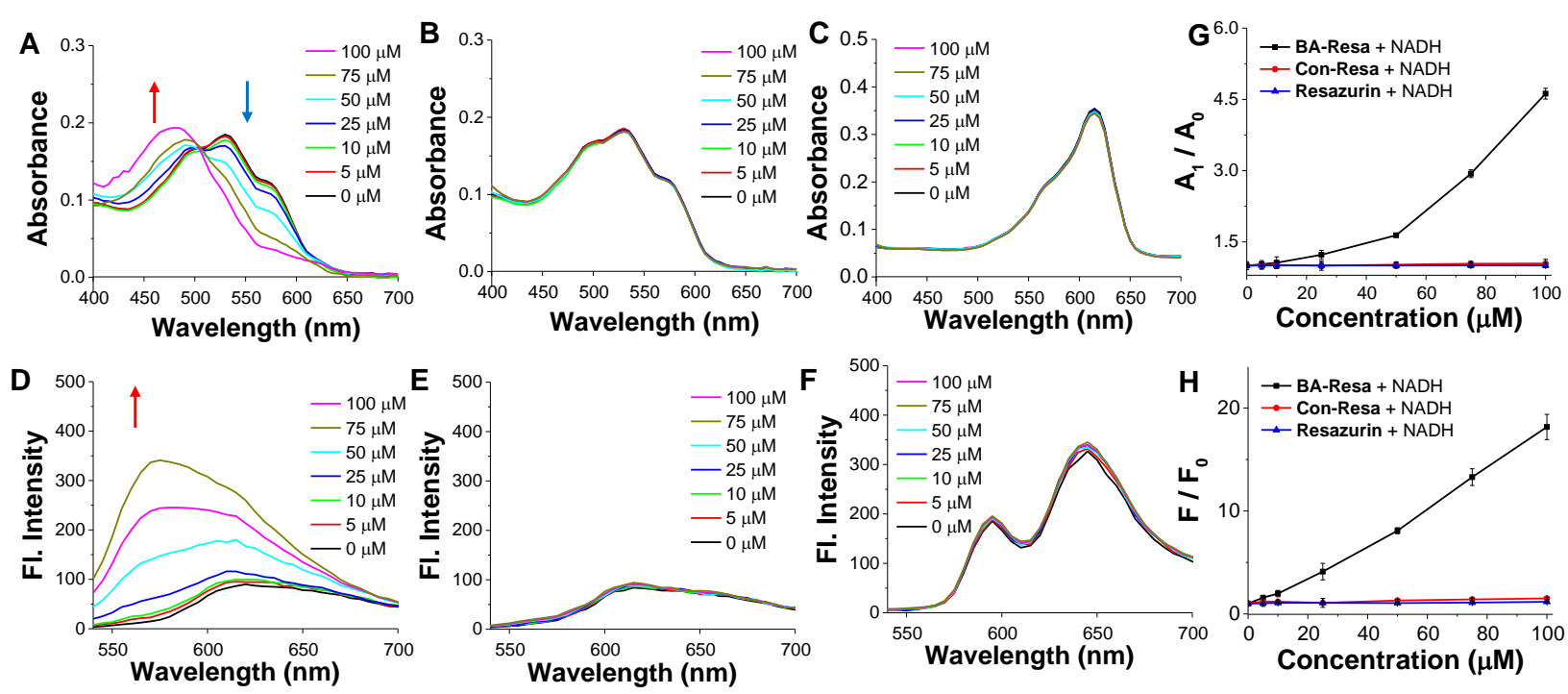

Figure S5. (A - C) UV-Vis absorption and (D - F) fluorescence spectra of BA-Resa (A, D), Con-Resa (B, E) and Resazurin $(C, F)$ in the presence of NADH as a function of concentration $(0-100 \mu \mathrm{M})$. (G,H) Plot of the UV absorbance ratiO $\left(\mathrm{A}_{1} / \mathrm{A}_{0}\right)$ and fluorescence intensity ratio $\left(\mathrm{F} / \mathrm{F}_{0}\right)$ of probe BA-Resa, Con-Resa, and Resazurin in the NADH titration $(0-100 \mu \mathrm{M})$. BA-Resa: $\mathrm{A}_{480} / \mathrm{A}_{575}$, Resazurin: A575/A610. Measurement condition: [probe] = $10 \mu \mathrm{M}, 10 \mathrm{mM}$ phosphate buffer saline ( $\mathrm{pH} 9.5$ ) solution, DMSO/PBS buffer (v/v, 1/1), $37{ }^{\circ} \mathrm{C}, \lambda_{\mathrm{ex}}=480 \mathrm{~nm}$, incubation time: $40 \mathrm{~min}$.

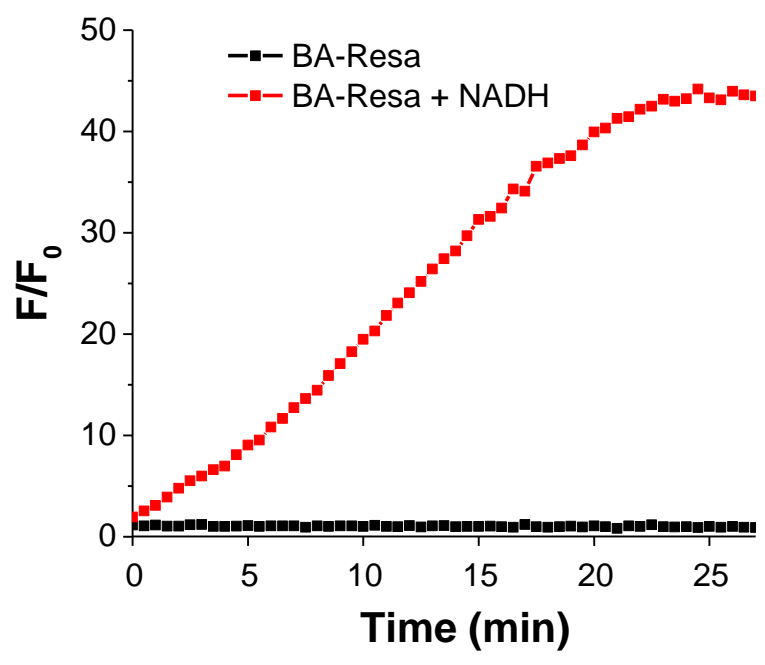

Figure S6. Time dependence of the fluorescence intensity change in the presence/absence of $50 \mu \mathrm{M} N A D H . F / F_{0}$ represents the fluorescence intensity ratio $(575 \mathrm{~nm})$ and $F_{0}$ is the initial fluorescence intensity $(575 \mathrm{~nm})$ of BAResa in the absence of NADH. Measurement condition: [BA-Resa] $=10 \mu \mathrm{M}, 10 \mathrm{mM}$ phosphate buffer saline (pH 9.5) solution, DMSO/PBS (1/99), $37^{\circ} \mathrm{C}, \lambda \mathrm{ex}=480 \mathrm{~nm}$, time interval: $0.5 \mathrm{~min}$. 


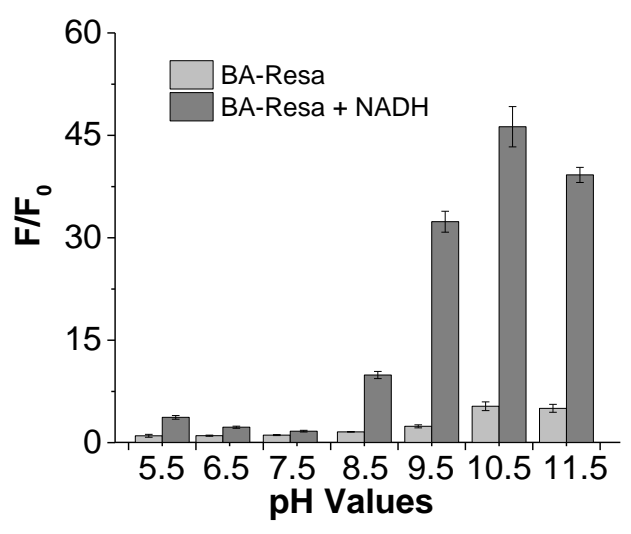

Figure S7. pH Effect to the fluorescent response of BA-Resa to NADH $(50 \mu \mathrm{M}) . \mathrm{F} / \mathrm{F}_{0}$ represents the fluorescence intensity ratio $(575 \mathrm{~nm})$ and $\mathrm{F}_{0}$ is the initial fluorescence intensity $(575 \mathrm{~nm})$ of BA-Resa in the absence of NADH at $\mathrm{pH}$ 5.5. Measurement condition: [BA-Resa] $=10 \mu \mathrm{M},[\mathrm{NADH}]=50 \mu \mathrm{M}, 10 \mathrm{mM}$ phosphate buffer saline solution, DMSO/PBS (1/99), $37{ }^{\circ} \mathrm{C}, \lambda \mathrm{ex}=480 \mathrm{~nm}$, and incubation time: 20 min. Results are expressed as mean \pm standard deviation of three independent experiments.

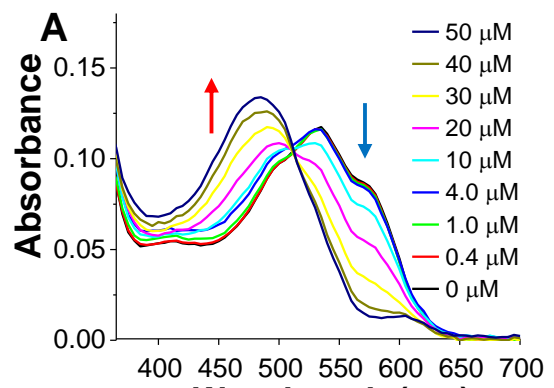

Wavelength $(\mathrm{nm})$
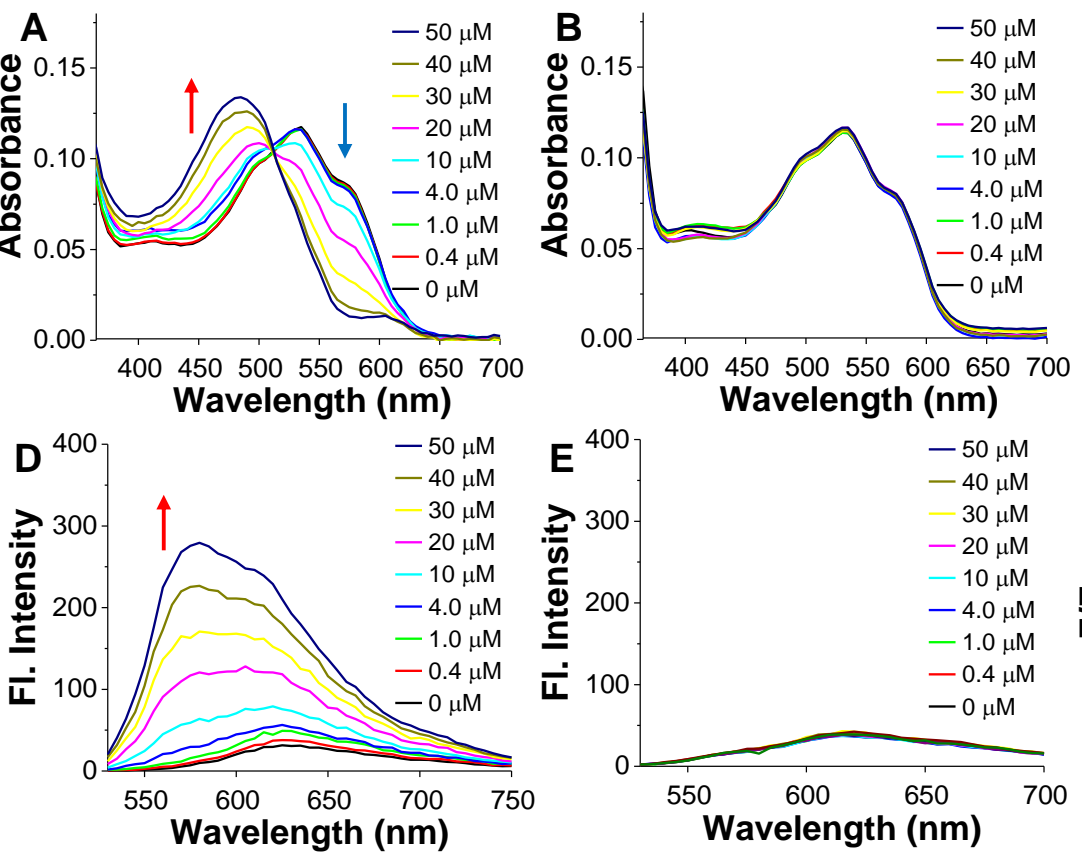

Wavelength $(\mathbf{n m})$

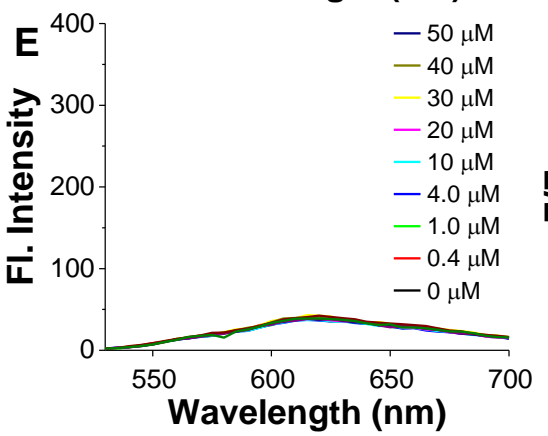

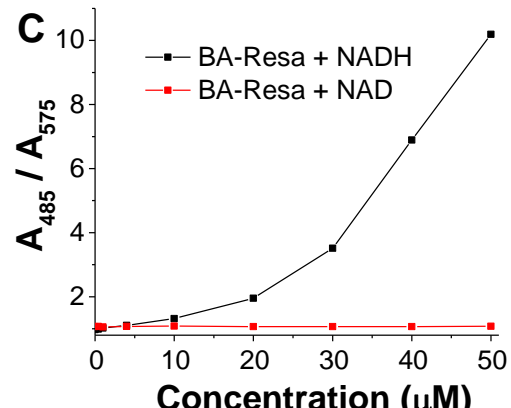

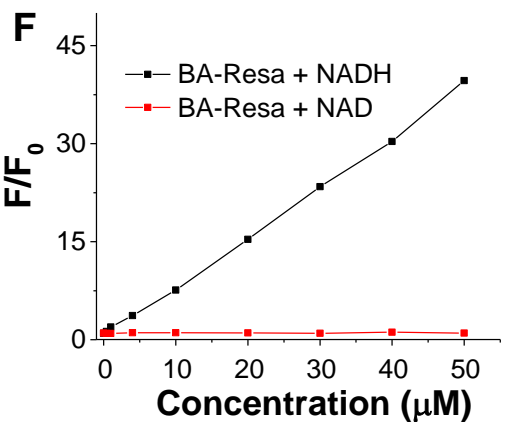

Figure S8. (A,B) UV-Vis absorption and (D,E) fluorescence spectra of BA-Resa in the presence of NADH (A,D) and $\mathrm{NAD}^{+}(\mathrm{B}, \mathrm{E})$ as a function of concentration $(0-50 \mu \mathrm{M})$. C,F) Plots of the absorbance ratio $\left(\mathrm{A}_{485} / \mathrm{A}_{575}\right)$ and fluorescence intensity ratio $\left(\mathrm{F} / \mathrm{F}_{0}\right)$ in the $\mathrm{NADH}$ and $\mathrm{NAD}^{+}$titration $(0-50 \mu \mathrm{M}) . \mathrm{F} / \mathrm{F}_{0}$ represents the fluorescence intensity ratio $(575 \mathrm{~nm})$ and $\mathrm{F}_{0}$ is the initial fluorescence intensity $(575 \mathrm{~nm})$ of BA-Resa in the absence of NADH or $\mathrm{NAD}^{+}$. Measurement condition: [BA-Resa] $=10 \mu \mathrm{M}, 10 \mathrm{mM}$ phosphate buffer saline (pH 9.5) solution, DMSO/PBS (1/99), $37^{\circ} \mathrm{C}, \lambda_{\mathrm{ex}}=480 \mathrm{~nm}$, and incubation time: $20 \mathrm{~min}$. 

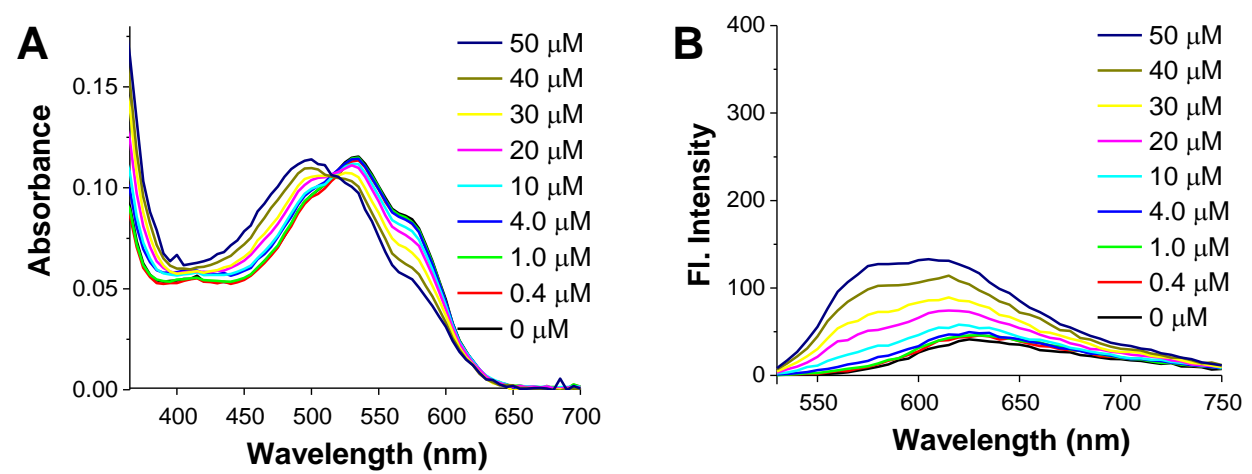

Figure S9. (A) UV absorption and (B) fluorescence spectra of BA-Resa in the presence of NADPH as a function of concentration $(0-50 \mu \mathrm{M})$. Measurement condition: [BA-Resa] $=10 \mu \mathrm{M}, 10 \mathrm{mM}$ phosphate buffer saline $(\mathrm{pH}$ 9.5) solution, DMSO/PBS (1/99), $37^{\circ} \mathrm{C}, \lambda_{\mathrm{ex}}=480 \mathrm{~nm}$, and incubation time: $20 \mathrm{~min}$.

A<smiles>COc1ccc2nc3ccc(=O)cc-3oc2c1</smiles>

Met-Resorufin

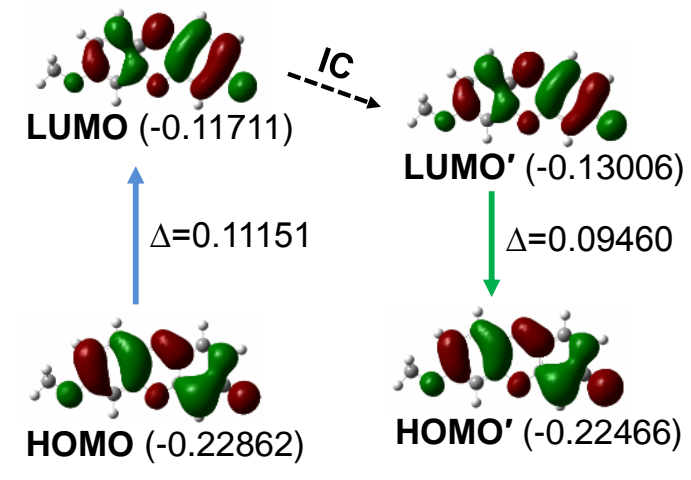

B<smiles>COc1ccc2c(c1)oc1cc(=O)ccc-1[n+]2[O-]</smiles>

Met-Resazurin

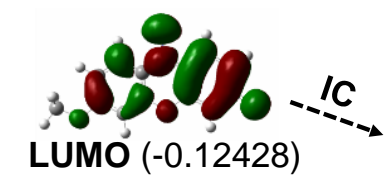

$\Delta=0.10425$

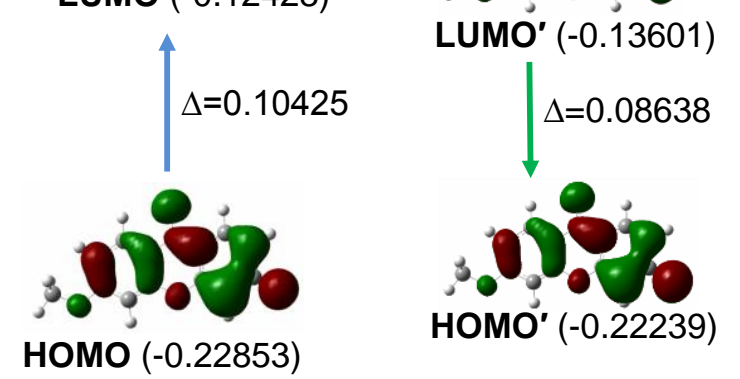

Figure S10. The frontier molecular orbitals (MOs) of Met-Resorufin (A) and Met-Resazurin (B) involved in the vertical excitation (i.e. Energy level, the left columns) and emission (right columns) shown in solid line. The vertical excitation related calculations were based on the optimized ground state $\left(\mathrm{S}_{0}\right.$ state), the emission related calculations were based on the optimized excited state ( $S_{1}$ state), at the B3LYP/6- 31G (d)/level using Gaussian 09W. The electron distribution at HOMO and LUMO was shown in red and green color. IC stands for internal conversion (dash lines). 

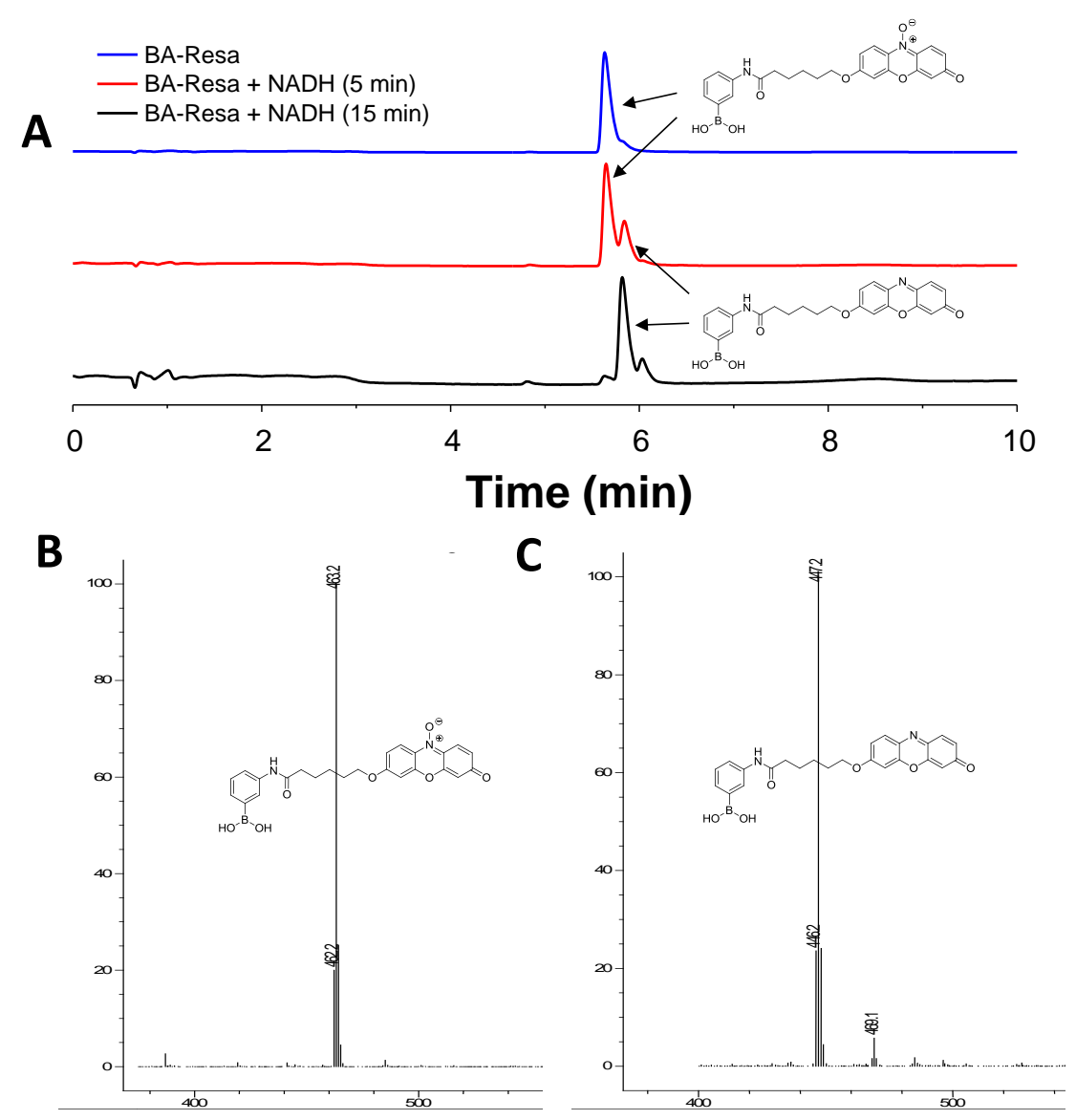

Figure S11. High Performance Liquid Chromatography (HPLC) spectrum indicating the reaction between probe BA-Resa and NADH. The absorbance signals was collected at $550 \mathrm{~nm}$. Measurement condition: [BA-Resa] $=100$ $\mu \mathrm{M},[\mathrm{NADH}]=1 \mathrm{mM}, 10 \mathrm{mM}$ phosphate buffer saline $(\mathrm{pH} 9.5)$ solution, DMSO/PBS $(1 / 99), 37{ }^{\circ} \mathrm{C}$. Mobile phase condition (water/acetonitrile): 0 min, $95 \%$ water; 1 min, $90 \%$ water; 8 min, $5 \%$ water; 8.5 min, 5\% water; 9 min, 95\% water; $10 \mathrm{~min}, 95 \%$ water. Mobile phase contains $0.1 \%$ formic acid. B,C) the mass spectra of BA-Resa and BA-Resa-P. The boronic acid in the probe can work as catalyst to accelerate the reduction in sensing process rather than a binding group changing fluorescent intensity (Fig. 2-4). Specifically, once the boronic acid of probe binds with NADH, the spatial distance between them is significantly reduced, then the sensing process could be accelerated and achieved in a short time. Meanwhile, the reversible and fast reaction between boronic acid and diols of NADH promote the continuous sensing process (rate constant of esterification: 102-103 $\mathrm{M}^{-1} \mathrm{~s}^{-1}$, Inorg. Chem. 1992, 31, 3243). 


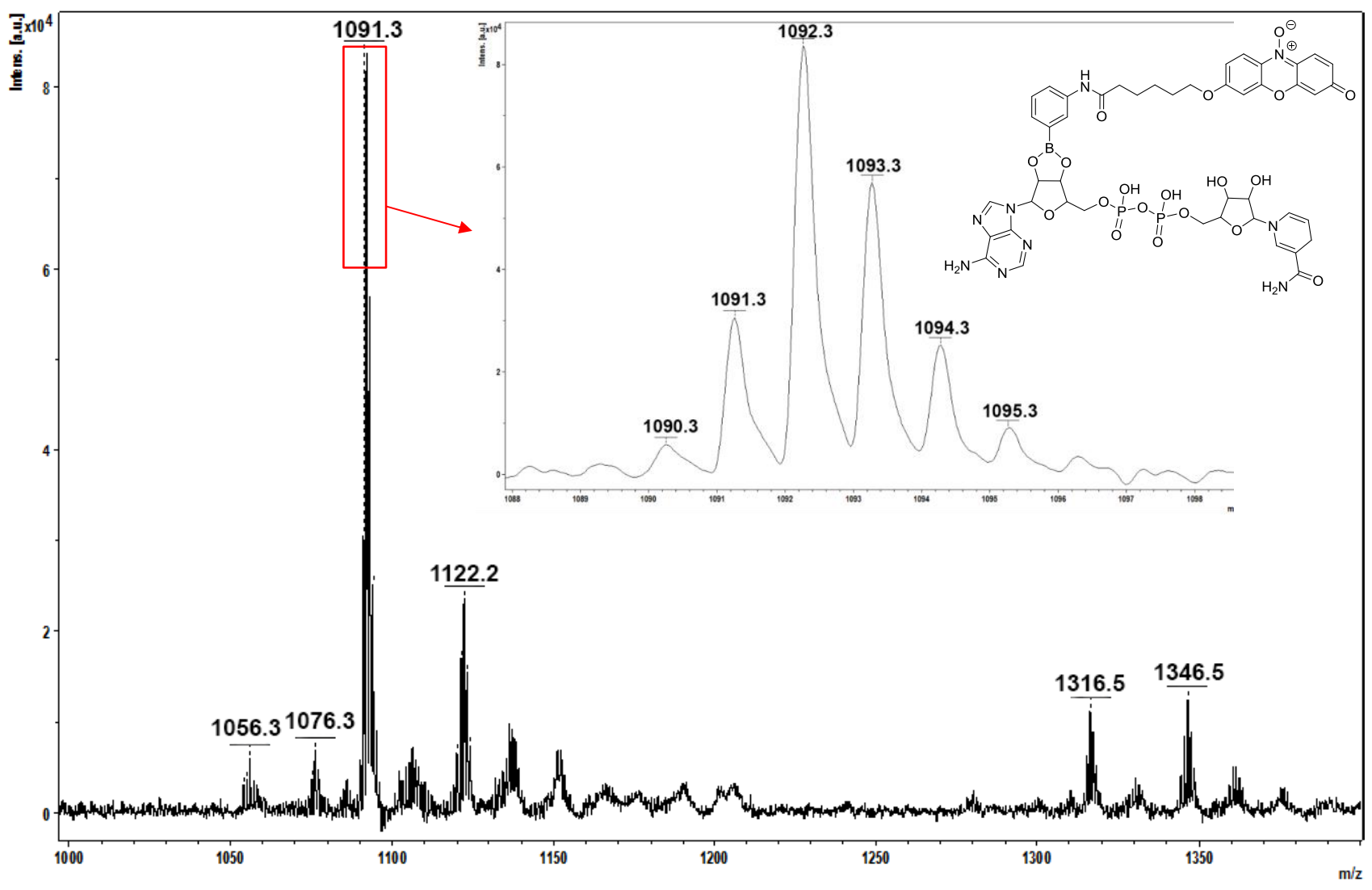

Figure S12. MALDI-TOF mass spectra of probe BA-Resa binding with NADH. Positive signals of the product of BA-Resa and NADH were indicated by peaks 1090.3 - 1095.3 (the top right enlarged figure). Probe and NADH were dissolved in methanol/water (1/1) mixture.
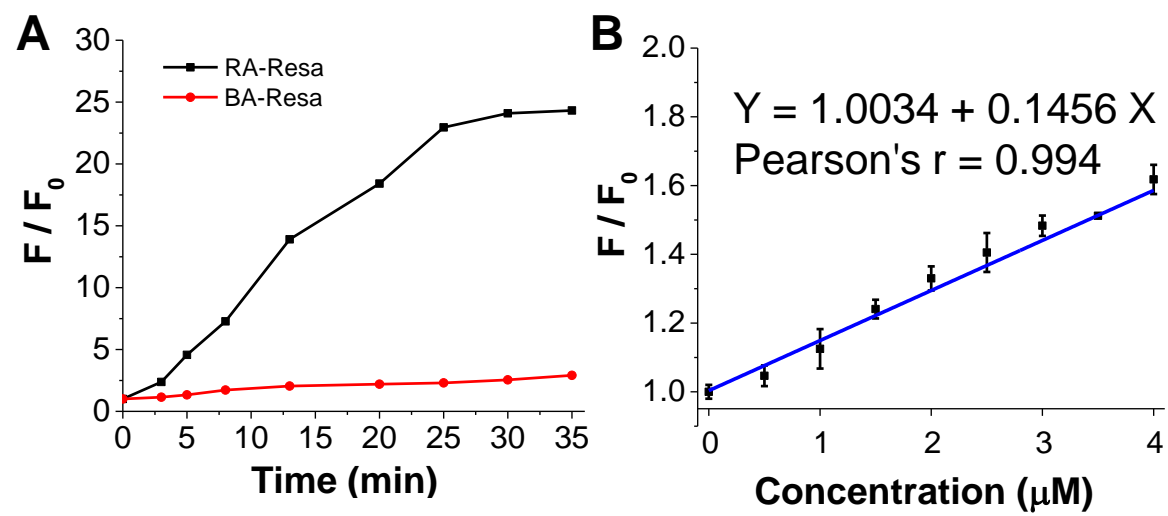

Figure S13. A) Time dependence of the fluorescence intensity change of BA-Resa and RA-Resa in the presence of $100 \mu \mathrm{M}$ NADH at physiological $\mathrm{pH}$. Measurement condition: [BA-Resa] $=$ [RA-Resa] $=10 \mu \mathrm{M}, 10 \mathrm{mM}$ phosphate buffer saline (pH 7.4) solution, DMSO/PBS (1/99), $\lambda \mathrm{ex}=480 \mathrm{~nm}, 37^{\circ} \mathrm{C}$. B) Curve-fitting analysis of 
the fluorescence intensity at $575 \mathrm{~nm}$ in the NADH titration $(0-4 \mu \mathrm{M}) . \mathrm{F} / \mathrm{F}_{0}$ represents the fluorescence intensity ratio $(575 \mathrm{~nm})$ and $\mathrm{F}_{0}$ is the initial fluorescence intensity $(575 \mathrm{~nm})$ of RA-Resa in the absence of NADH.

Measurement condition: [RA-Resa] $=2 \mu \mathrm{M}, 10 \mathrm{mM}$ phosphate buffer saline (pH 7.4) solution, DMSO/PBS (1/99), $\lambda$ ex $=480 \mathrm{~nm}, 37^{\circ} \mathrm{C}$, and incubation time: $20 \mathrm{~min}$. Results are expressed as mean \pm standard deviation of three independent experiments.

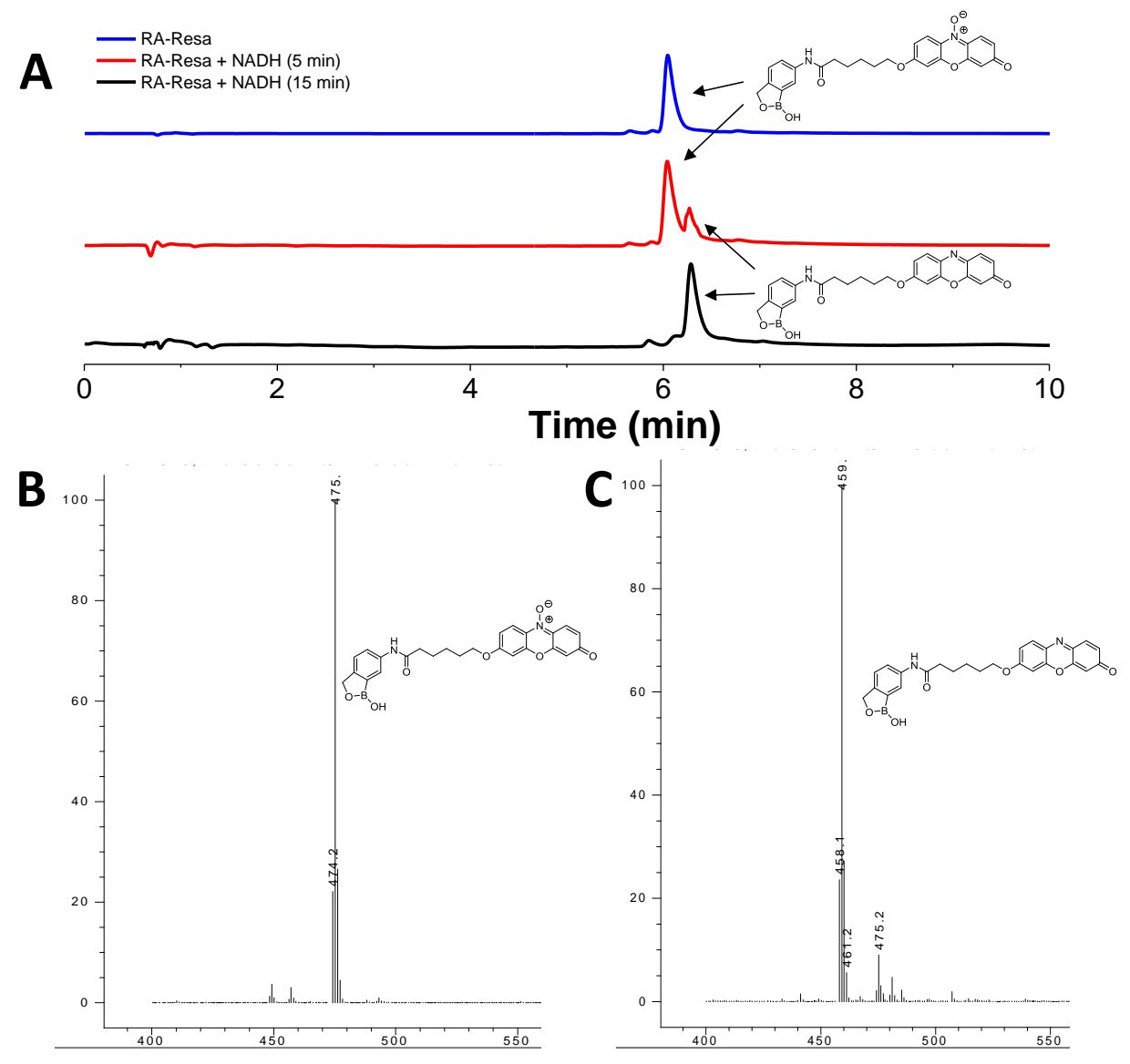

Figure S14. High Performance Liquid Chromatography (HPLC) spectrum indicating the reaction between probe BA-Resa and NADH. The absorbance signals was collected at $550 \mathrm{~nm}$. Measurement condition: [RA-Resa] $=100$ $\mu \mathrm{M},[\mathrm{NADH}]=1 \mathrm{mM}, 10 \mathrm{mM}$ phosphate buffer saline $\left(\mathrm{pH}\right.$ 7.4) solution, DMSO/PBS (1/99), $37{ }^{\circ} \mathrm{C}$. Mobile phase condition (water/acetonitrile): $0 \mathrm{~min}, 95 \%$ water; $1 \mathrm{~min}, 90 \%$ water; $8 \mathrm{~min}, 5 \%$ water; $8.5 \mathrm{~min}, 5 \%$ water; $9 \mathrm{~min}$, 95\% water; 10 min, $95 \%$ water. Mobile phase contains $0.1 \%$ formic acid. B,C) the mass spectra of RA-Resa and RA-Resa-P. 


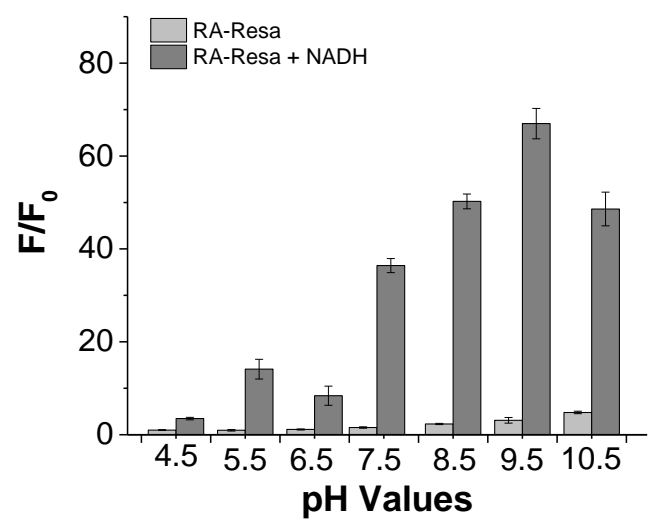

Figure S15. pH Effect on the fluorescence response of RA-Resa to NADH $(100 \mu \mathrm{M})$. F/F $\mathrm{F}_{0}$ represents the fluorescence intensity ratio $(575 \mathrm{~nm})$ and $\mathrm{F}_{0}$ is the initial fluorescence intensity $(575 \mathrm{~nm})$ of RA-Resa in the absence of NADH at pH 4.5. Measurement condition: [RA-Resa] $=10 \mu \mathrm{M},[\mathrm{NADH}]=100 \mu \mathrm{M}, 10 \mathrm{mM}$ phosphate buffer saline solution, DMSO/PBS (1/99), $\lambda \mathrm{ex}=480 \mathrm{~nm}, 37^{\circ} \mathrm{C}$, and incubation time: $15 \mathrm{~min}$. Results are expressed as mean \pm standard deviation of three independent experiments.

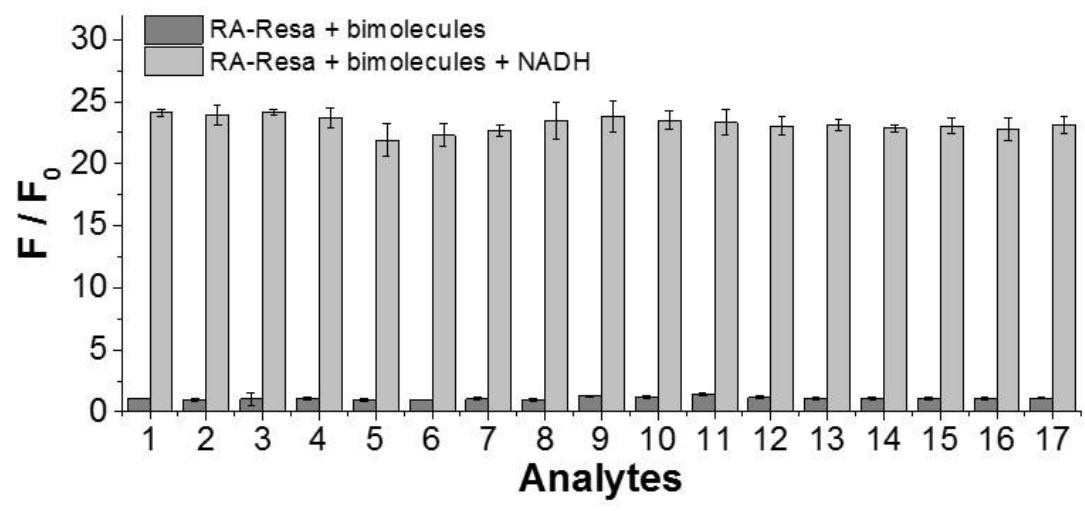

Figure S16. Fluorescence response of RA-Resa to NADH in the presence of various biomolecules. Analytes (2-7, $1 \mathrm{mM}$; 8-17, $100 \mu \mathrm{M}$ ): 1) buffer, 2) $\mathrm{Ca}^{2+}$, 3) $\mathrm{K}^{+}$, 4) $\mathrm{Na}^{+}$, 5) $\mathrm{Fe}^{3+}$, 6) $\mathrm{Zn}^{2+}$, 7) $\mathrm{Mg}^{2+}$, 8) Tyrosine, 9) Cysteine, 10) Methionine, 11) GSH, 12) Glucose, 13) Ribose, 14) Fructose, 15) ATP, 16) ADP, 17) NAD ${ }^{+}$. F/F $F_{0}$ represents the fluorescence intensity ratio and $\mathrm{F}_{0}$ is the initial fluorescence intensity at $575 \mathrm{~nm}$ of RA-Resa in the absence of NADH. Measurement condition: [RA-Resa] $=10 \mu \mathrm{M}, 10 \mathrm{mM}$ phosphate buffer saline ( $\mathrm{pH}$ 9.5) solution, $\lambda \mathrm{ex}=$ $480 \mathrm{~nm} .37^{\circ} \mathrm{C}$, and incubation time: $20 \mathrm{~min}$. Results are expressed as mean \pm standard deviation of three independent experiments. 

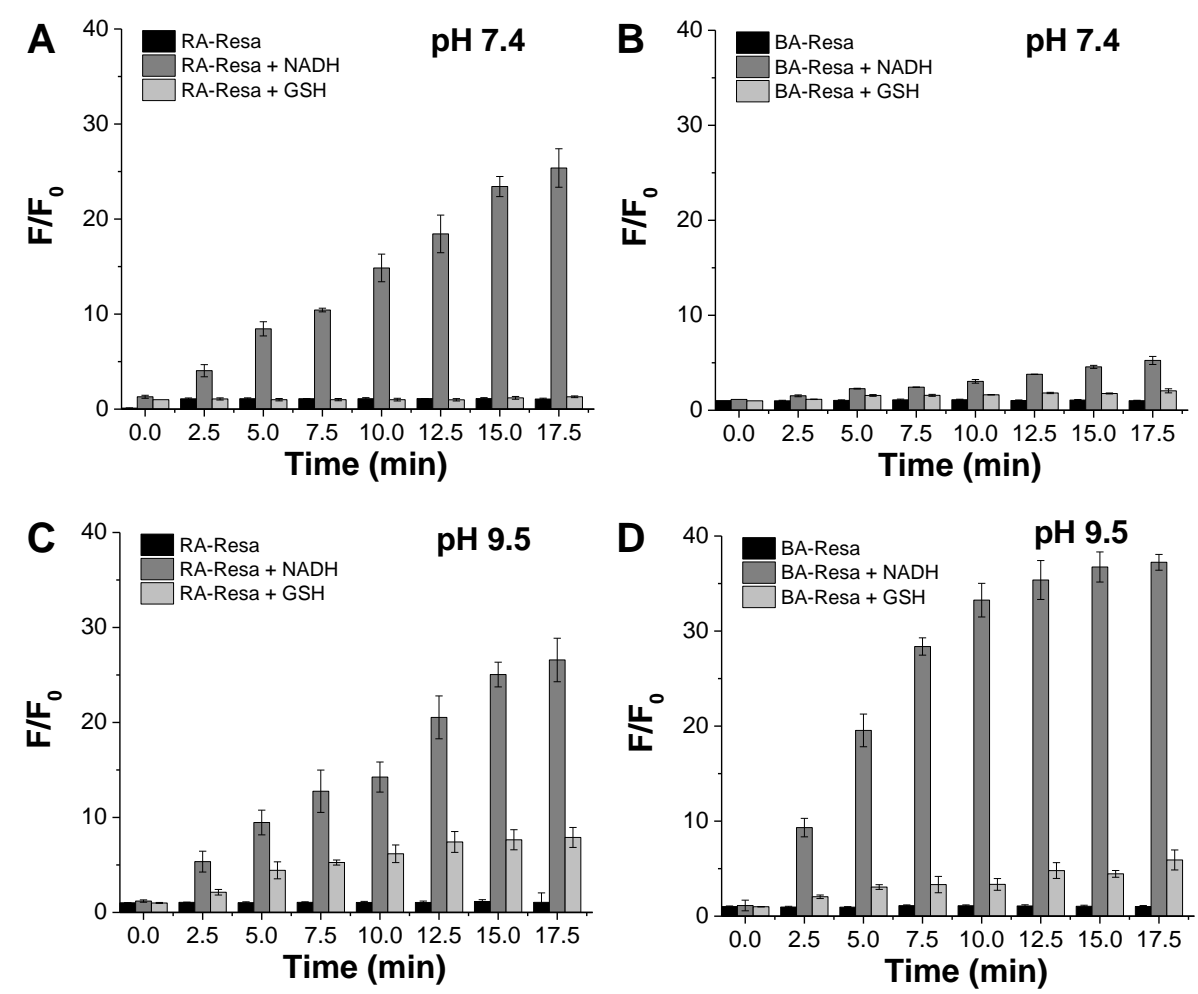

Figure S17. Time dependence of the fluorescence intensity change of RA-Resa $(A, C)$ and BA-Resa $(B, D)$ in the presence of NADH and GSH at pH $7.4(\mathrm{~A}, \mathrm{~B})$ or $\mathrm{pH} 9.5$ (C,D) buffer solution respectively. F/F $\mathrm{F}_{0}$ represents the fluorescence intensity ratio $(575 \mathrm{~nm})$ and $\mathrm{F}_{0}$ is the initial fluorescence intensity $(575 \mathrm{~nm})$ of RA-Resa or BA-Resa in the absence of NADH. Measurement condition: $[$ BA-Resa $]=[$ RA-Resa $]=10 \mu \mathrm{M},[\mathrm{NADH}]=[\mathrm{GSH}]=100$ $\mu \mathrm{M}, 10 \mathrm{mM}$ phosphate buffer saline ( $\mathrm{pH} 7.4$ and 9.5) solution, DMSO/PBS (1/99), $\lambda \mathrm{ex}=480 \mathrm{~nm}, 37^{\circ} \mathrm{C}$. Results are expressed as mean \pm standard deviation of three independent experiments. 

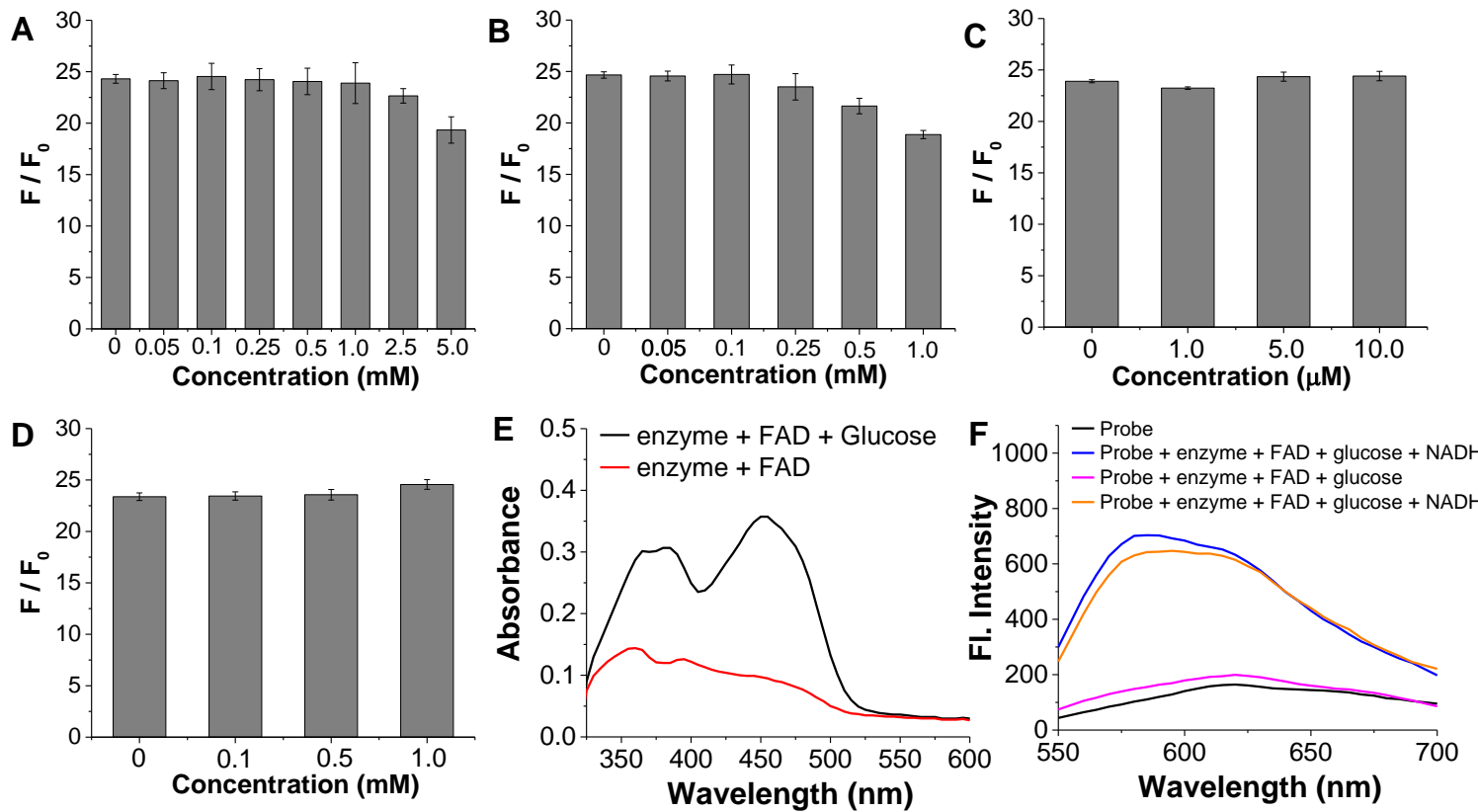

Figure S18. Fluorescence response of RA-Resa to NADH in the presence of Ribose (A), ATP (B), $\mathrm{H}_{2} \mathrm{O}_{2}(C)$, Tetrasodium pyrophosphate (D), and $\mathrm{FADH}_{2}(\mathrm{E}, \mathrm{F})$. E) The absorption spectrum of $\mathrm{FADH}_{2}$ produced in the glucose oxidase enzyme system after incubation for $1 \mathrm{~min}$. F) The fluorescence spectra of probe responding to NADH $(50 \mu \mathrm{M})$ and $\mathrm{FADH}_{2}$. Incubation time: $20 \mathrm{~min} \mathrm{~F} / \mathrm{F}_{0}$ represents the fluorescence intensity ratio $(575 \mathrm{~nm})$ and $\mathrm{F}_{0}$ is the initial fluorescence intensity $(575 \mathrm{~nm})$ of RA-Resa in the absence of NADH. Measurement condition:

$[$ RA-Resa $]=10 \mu \mathrm{M},[\mathrm{NADH}]=100 \mu \mathrm{M},[$ Ribose $]=0.05-5.0 \mathrm{mM},[\mathrm{ATP}]=0.05-1.0 \mathrm{mM},\left[\mathrm{H}_{2} \mathrm{O}_{2}\right]=1-10 \mu \mathrm{M}$, [Tetrasodium pyrophosphate] $=0.1-1.0 \mathrm{mM}$, [glucose oxidase] $=48 \mathrm{U} / 100 \mu \mathrm{L}$, [glucose] $=0.5 \mathrm{mM}$,

$\left[\mathrm{FAD}+\mathrm{FADH}_{2}\right]=50 \mu \mathrm{M}, 10 \mathrm{mM}$ phosphate buffer saline (pH 7.4) solution, DMSO/PBS (1/99), $\lambda \mathrm{ex}=480 \mathrm{~nm}, 37$ ${ }^{\circ} \mathrm{C}$, and incubation time: $30 \mathrm{~min}$. Results are expressed as mean \pm standard deviation of three independent experiments. 


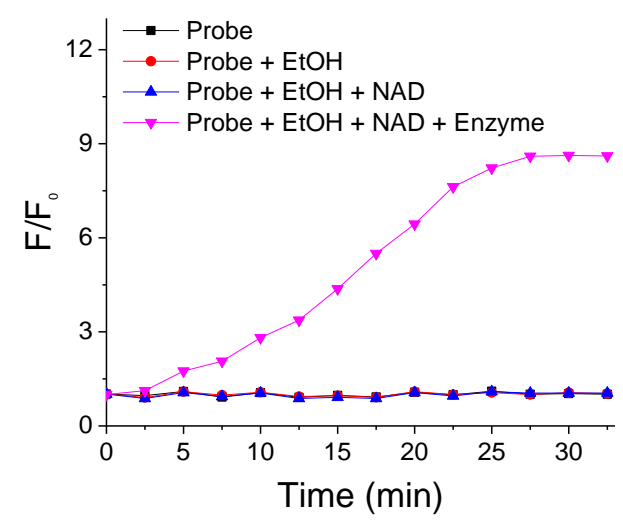

Figure S19. Plots of fluorescent intensity of RA-Resa in the absence/presence of alcohol dehydrogenase at physiological $\mathrm{pH}$. $\mathrm{F} / \mathrm{F}_{0}$ represents the fluorescence intensity ratio and $\mathrm{F}_{0}$ is the initial fluorescence intensity at 575 $\mathrm{nm}$ of RA-Resa in the absence of enzyme. Measurement condition: [Probes] $=10 \mu \mathrm{M},[\mathrm{EtOH}]=10 \mathrm{mM},\left[\mathrm{NAD}^{+}\right]$ $=50 \mu \mathrm{M}, 10 \mathrm{mM}$ phosphate buffer saline (pH 7.4) solution, DMSO/PBS (1/99), $\lambda \mathrm{ex}=480 \mathrm{~nm}, 37^{\circ} \mathrm{C}$.

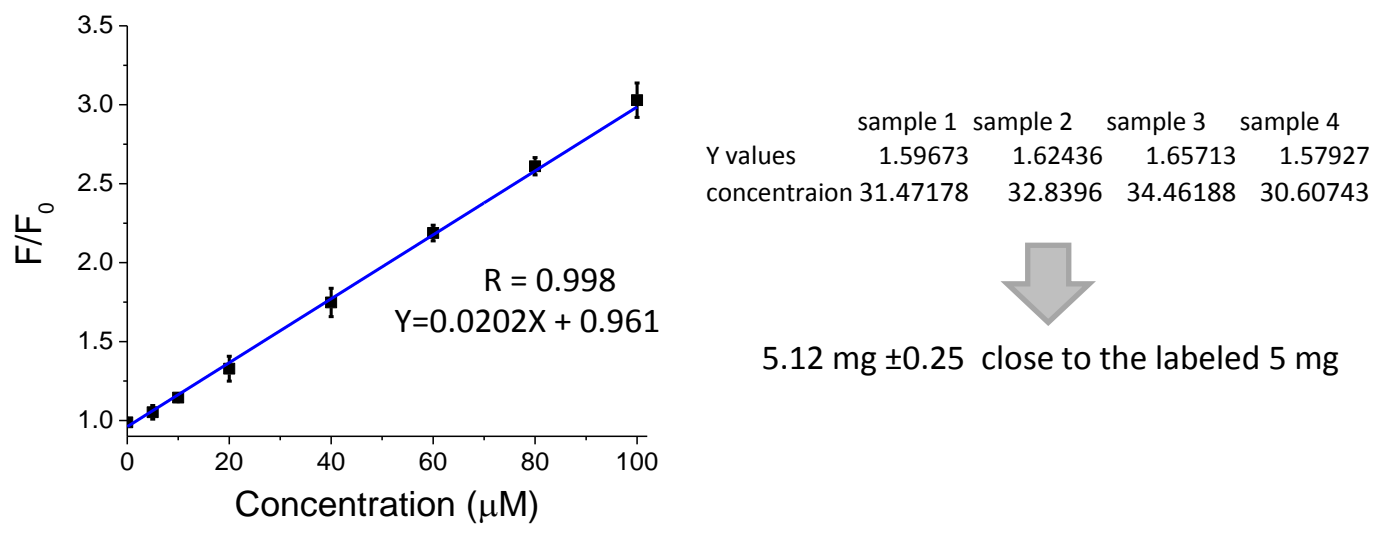

Figure S20. The linearity of fluorescence intensity versus concentration in the NADH quantification of health care products. $11.2 \mathrm{mg}$ was obtained from the $202 \mathrm{mg}$ NADH tablet and dissolved in PBS (pH 7.4). The experiments were repeated four times. $\mathrm{F} / \mathrm{F}_{0}$ represents the fluorescence intensity ratio $(575 \mathrm{~nm})$ and $\mathrm{F}_{0}$ is the initial fluorescence intensity (575 nm) of RA-Resa in the absence of NADH. Measurement condition: [Probes] $=10 \mu \mathrm{M}, 10 \mathrm{mM}$ phosphate buffer saline (pH 7.4) solution, DMSO/PBS (1/99), $\lambda \mathrm{ex}=480 \mathrm{~nm} .37^{\circ} \mathrm{C}$, incubation time: 5 min. Results are expressed as mean \pm standard deviation of three independent experiments. 


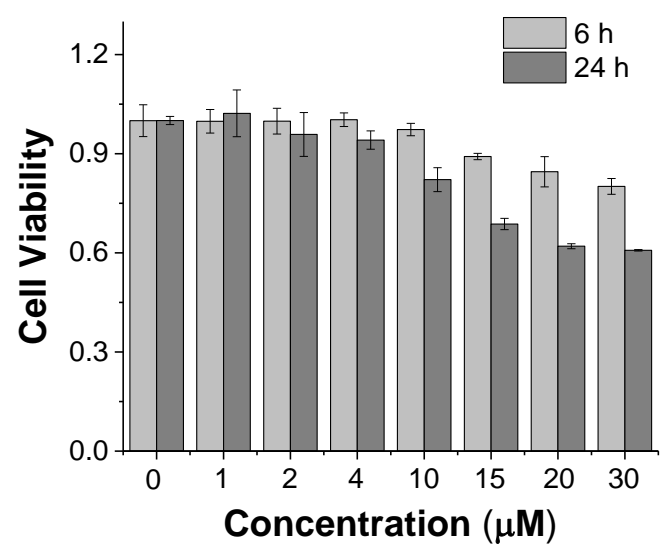

Figure S21. Cytotoxic effect of RA-Resa. OSCC cells were treated with each concentration of probe for 6 and 24 h. MTT assay was used to quantify the cell viability. Results are expressed as mean \pm standard deviation of three independent experiments.

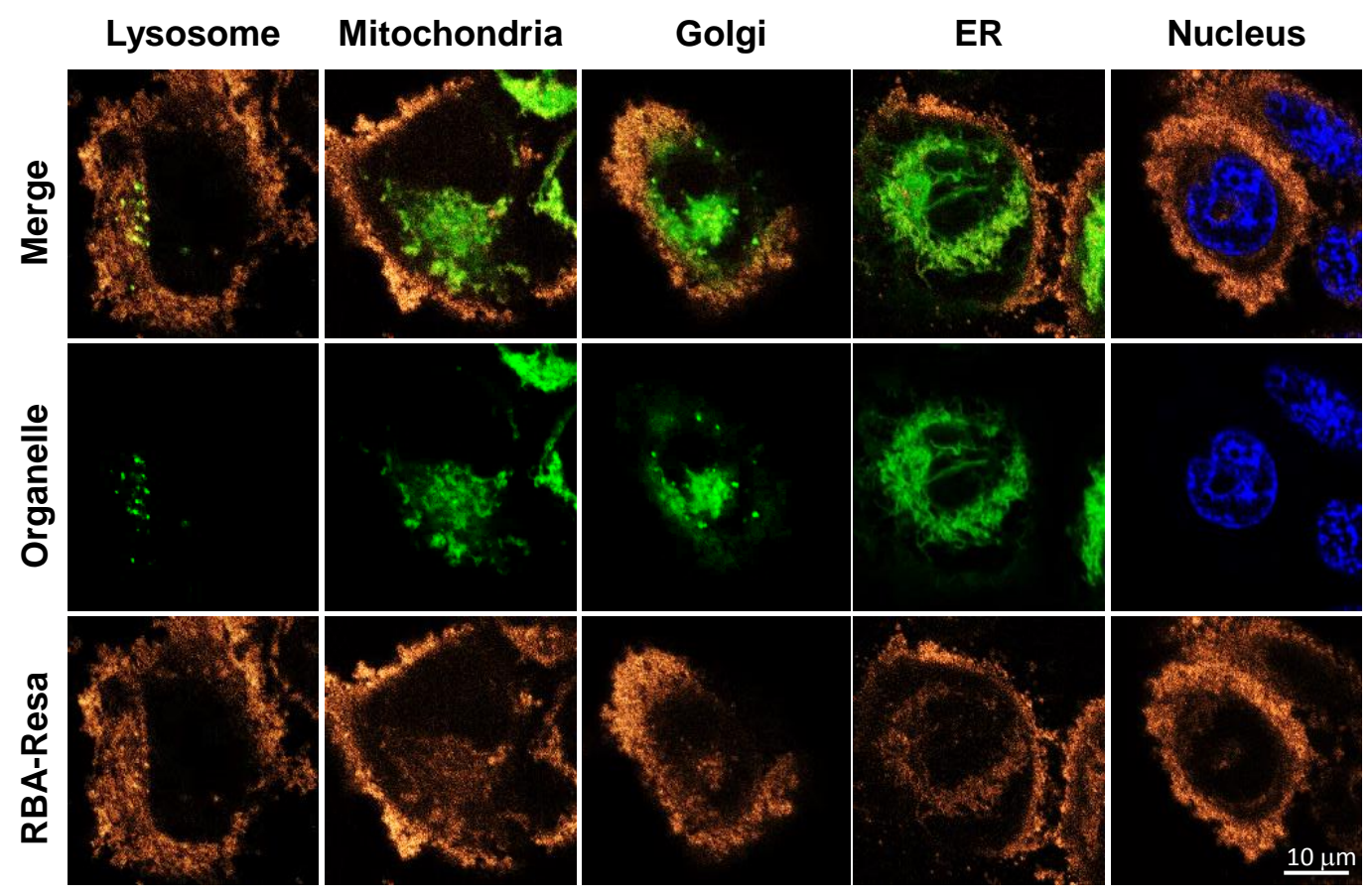

Figure 22. Confocal microscopic images of probe RA-Resa $(5 \mu \mathrm{M}, 30 \mathrm{~min})$ and organelle markers stained live OSCC cells. Nucleus, Hoechst33342 (1ug/ml, 30 min), Mitochondria, MitoTracker (100 nM, 30 min), Lysosome LysoTracker (50 nM, $30 \mathrm{~min}$ ), Golgi, BODIPY FL C5 ceramide (1 uM, 60 min under $4{ }^{\circ} \mathrm{C}$ ), ER, ER-Tracker (100 $\mathrm{nM}, 30 \mathrm{~min})$. Scale bar: $10 \mu \mathrm{m}$. 


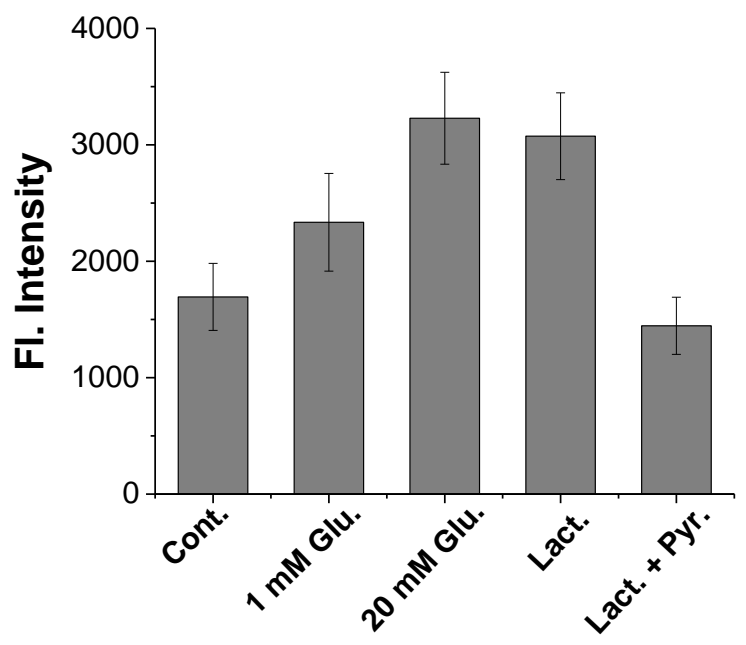

Figure S23. Quantification of fluorescence intensities of RA-Resa in live OSCC cells. After incubated with glucose $(1 \mathrm{mM}$ or $20 \mathrm{mM}, 0.5 \mathrm{~h})$ or lactate $(10 \mathrm{mM}, 10 \mathrm{~min})$ or lactate $(10 \mathrm{mM}, 10 \mathrm{~min})$ and pyruvate $(10 \mathrm{mM}, 10$ $\min )$, the live OSCC cells were further treated with RA-Resa $(5 \mu \mathrm{M})$ for another 15 min prior to imaging. In control group, the live OSCC cells were treated with RA-Resa $(5 \mu \mathrm{M})$ for $15 \mathrm{~min}$ in starvation state $(0.5 \mathrm{~h})$. Error bars are standard deviation (SD). Each data point was obtained from ROIs $(n=5)$ inside the cells, and the experiments were repeated for 5 times.

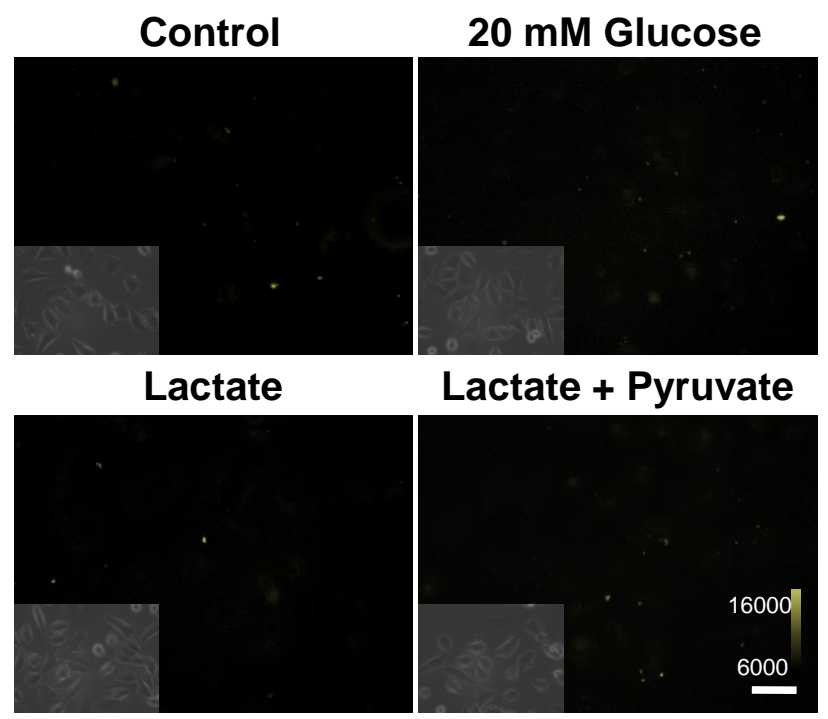

Figure S24. Microscopic images of probe Con-Resa ( $5 \mu \mathrm{M}, 15 \mathrm{~min}$ )-stained live OSCC cells after incubation in following conditions. A) no glucose for $30 \mathrm{~min}$; B) $20 \mathrm{mM}$ glucose for $30 \mathrm{~min}$; C) $10 \mathrm{mM}$ lactate for $10 \mathrm{~min}$; D) $10 \mathrm{mM}$ lactate and $5 \mathrm{mM}$ pyruvate for $10 \mathrm{~min}$. Scale bar: $50 \mu \mathrm{m}$. 


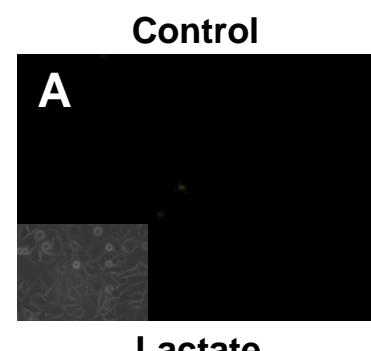
$10 \mathrm{mM}$ Glucose
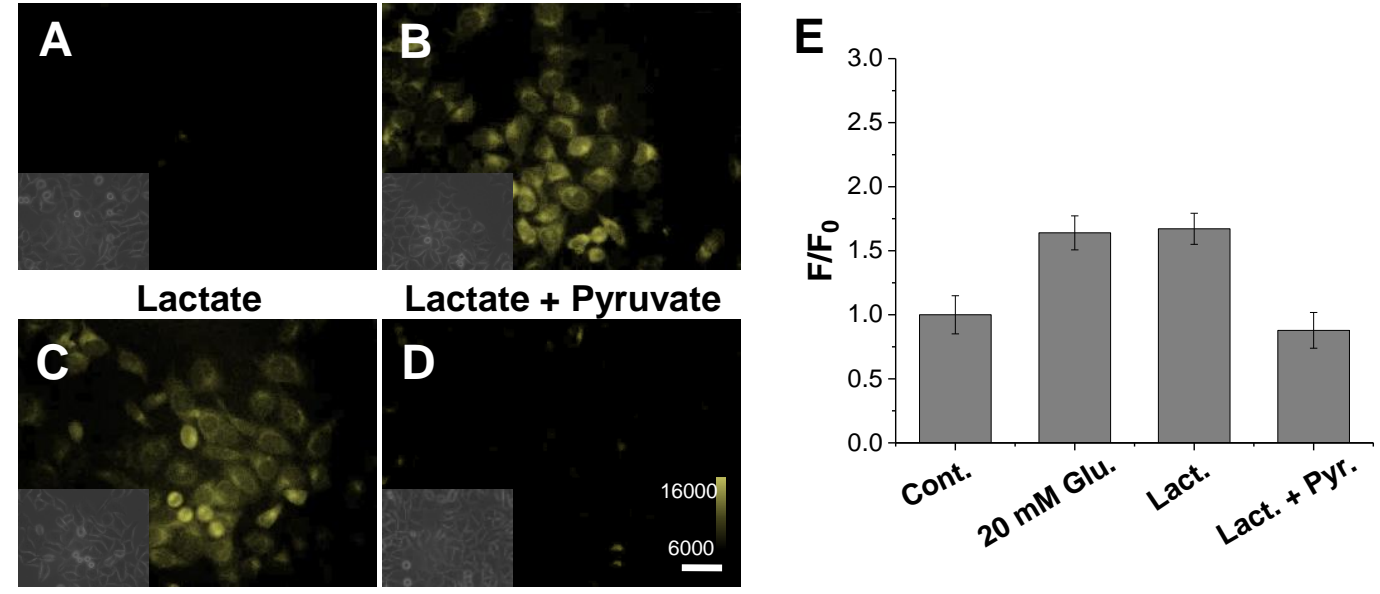

Figure S25. Microscopic images of probe BA-Resa (5 $\mu \mathrm{M}, 15 \mathrm{~min}$ )-stained live Hela cells after incubation in following conditions. A) no glucose for $30 \mathrm{~min}$; B) $20 \mathrm{mM}$ glucose for $30 \mathrm{~min}$; C) 10 $\mathrm{mM}$ lactate for $10 \mathrm{~min}$; D) $10 \mathrm{mM}$ lactate and $5 \mathrm{mM}$ pyruvate for $10 \mathrm{~min}$. Scale bar: $50 \mu \mathrm{m}$. E) Quantification of fluorescence intensities of RA-Resa in live OSCC cells. Error bars are standard deviation (SD). Each data point was obtained from ROIs $(n=5)$ inside the cells, and the experiments were repeated for 3 times.
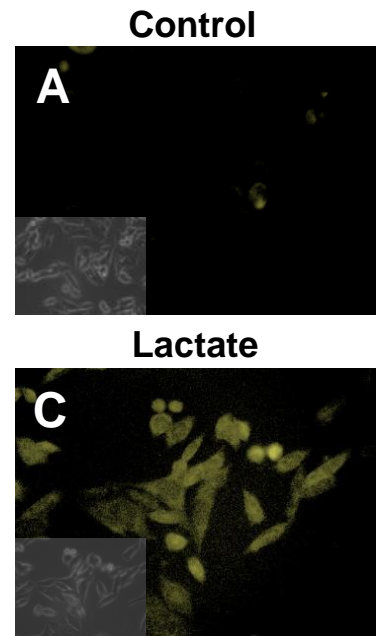

\section{$10 \mathrm{mM}$ Glucose}

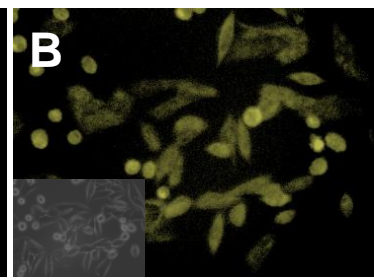

Lactate + Pyruvate

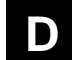

E

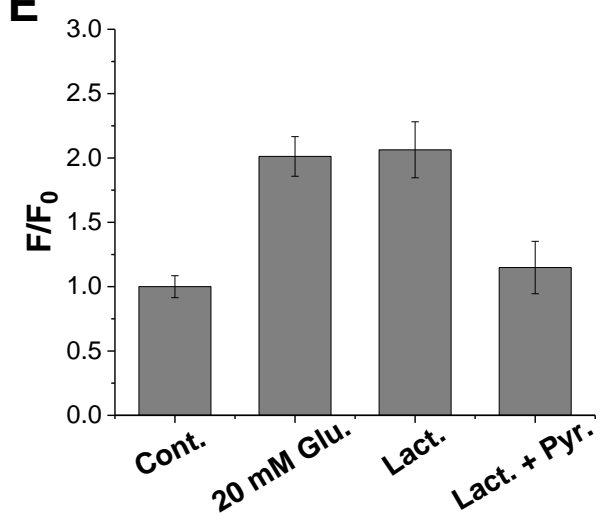

Figure S26. Microscopic images of probe RA-Resa $(5 \mu \mathrm{M}, 15 \mathrm{~min})$-stained live CHO cells after incubation in following conditions. A) no glucose for $30 \mathrm{~min}$; B) $20 \mathrm{mM}$ glucose for $30 \mathrm{~min}$; C) 10 $\mathrm{mM}$ lactate for $10 \mathrm{~min}$; D) $10 \mathrm{mM}$ lactate and $5 \mathrm{mM}$ pyruvate for $10 \mathrm{~min}$. Scale bar: $50 \mu \mathrm{m}$. E) Quantification of fluorescence intensities of RA-Resa in live OSCC cells. Error bars are standard deviation (SD). Each data point was obtained from ROIs $(n=5)$ inside the cells, and the experiments were repeated for 3 times. 

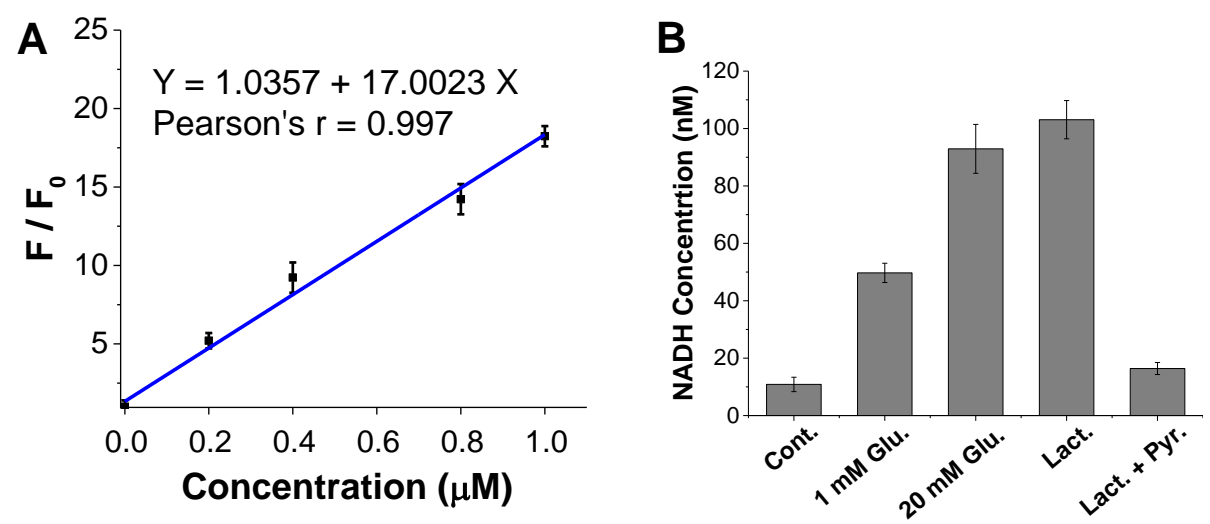

Figure S27. Quantification of NADH level in cells by NADH assay kit. $10^{5}$ live OSCC cells in 1.5 $\mathrm{mL}$ tubes were incubated with the following conditions: A) no glucose for $30 \mathrm{~min}$; B) $20 \mathrm{mM}$ glucose for $30 \mathrm{~min}$; C) $10 \mathrm{mM}$ lactate for $10 \mathrm{~min}$; D) $10 \mathrm{mM}$ lactate and $5 \mathrm{mM}$ pyruvate for $10 \mathrm{~min}$. The cells were shook very $5 \mathrm{~min}$. The NADH was extracted and measured based on the protocol in NADH kit (NAD/NADH Assay Kit, US Biological).

\section{Materials and General Experimental Methods}

All chemical reagents for the probe synthesis were obtained from Sigma Aldrich, Alfa Aesar, or MERCK, and used without further purification unless otherwise specified. The NADH dietary supplement was purchase from Ecological Formulas. NADH assay kit was purchased from US Biological (NAD/NADH Assay Kit). Column chromatography was carried out on Merck Silica Gel 60 (0.040-0.064 mm, 230-400 mesh). Synthetic reactions and analytical characterization were monitored by HPLC-MS (Agilient-1200 series) with a DAD detector and a single quadrupole mass spectrometer (6130 series) with an ESI probe. NMR spectra $\left({ }^{1} \mathrm{H}-300\right.$ or $500 \mathrm{MHz}$ and ${ }^{13} \mathrm{C}-75$ or 125 $\mathrm{MHz}$ ) were recorded on Bruker Avance 300 or 500 NMR spectrometers. The high resolution electron spray ionization (HR-ESI) mass spectra were obtained on a Bruker micrOTOFQII. Spectroscopic and quantum yield data were measured on spectroscopic measurements, performed on a fluorometer and UV/VIS instrument, Spectra Max M2 by Molecular Device (The slit width: $1 \mathrm{~nm}$ ). pH Value was determined by a Mettler Toledo S220 SEVENCOMPACT pH meter (Columbus, OH). Fluorescence microscopic images were obtained from a fluorescence Ti microscope (Nikon) 
inverted microscope with epifluorescence and phase contrast optics using $20 \times$ objective lenses. The orange fluorescence was collected by using an Ex $480 \mathrm{~nm} / 40$, Em 510nm/longpass filter. Confocal images were recorded from Nikon confocal microscope with 60x objective (3x zoom).

\section{Synthesis and Characterization}

Preparation of 4-6. 6-Bromohexanoic Acid (200 mg, 1.0 mmole), N-(3-Dimethylaminopropyl)-N'ethylcarbodiimide hydrochloride (229 mg, $1.2 \mathrm{mmole}$ ) and Hydroxybenzotriazole (183 mg, 1.2 mmole) were mixed and dissolved in $10 \mathrm{~mL}$ dichloromethane (DCM). After stirring for $5 \mathrm{~min}$, anilines (1.0 mmole) were added and stirred for $3 \mathrm{~h}$. The reaction was monitored by LC-MS and a product with reduced polarity was observed. Then $20 \mathrm{~mL}$ dichloromethane were added and extracted with water $(3 \times 30 \mathrm{~mL})$. The organic phase was collected and evaporated under vacuum. The product was used in the next step without further purification.

Preparation of RA-Resa, BA-Resa and Con-Resa. To a stirred solution of Resazurin (114 mg, $0.5 \mathrm{mmole}$ ) and potassium carbonate $(207 \mathrm{mg}, 1.5 \mathrm{mmole})$ in $5 \mathrm{~mL}$ dimethylformamide (DMF), compound 4, or 5, or $\mathbf{6}(0.15$ mmole) dissolved in $1 \mathrm{~mL}$ DMF was added respectively under argon atmosphere. The mixture was stirred at $75{ }^{\circ} \mathrm{C}$ for $24 \mathrm{~h}$. The reaction was monitored by LC-MS and a red product with reduced polarity was observed. After cooling to room temperature, $20 \mathrm{~mL}$ DCM was added and the mixture was extracted with water $(3 \times 50 \mathrm{~mL})$. The organic phase was collected and removed under vacuum condition. Then the mixture was purified by preparative TLC with a solvent system $\left(\mathrm{CH}_{2} \mathrm{Cl}_{2}: \mathrm{MeOH}=100: 6\right)$ and red solid products were obtained.

RA-Resa. Yield: $174.5 \mathrm{mg}(73.5 \%){ }^{1} \mathrm{H}$ NMR (300 MHz, DMSO) $\delta 8.04$ (d, $\left.J=9.3 \mathrm{~Hz}, 1 \mathrm{H}\right), 8.00-$ $7.90(\mathrm{~m}, 2 \mathrm{H}), 7.58(\mathrm{~d}, J=8.0 \mathrm{~Hz}, 1 \mathrm{H}), 7.29(\mathrm{~d}, J=8.3 \mathrm{~Hz}, 1 \mathrm{H}), 7.17$ (d, $J=2.3 \mathrm{~Hz}, 1 \mathrm{H}), 7.04(\mathrm{dd}, J$ $=9.2,2.4 \mathrm{~Hz}, 1 \mathrm{H}), 6.65(\mathrm{~d}, J=10.1 \mathrm{~Hz}, 1 \mathrm{H}), 6.14(\mathrm{~d}, J=1.8 \mathrm{~Hz}, 1 \mathrm{H}), 4.91(\mathrm{~s}, 2 \mathrm{H}), 4.15(\mathrm{t}, J=6.3$ $\mathrm{Hz}, 2 \mathrm{H}), 2.34$ (t, $J=7.2 \mathrm{~Hz}, 2 \mathrm{H}), 1.86-1.74(\mathrm{~m}, 2 \mathrm{H}), 1.71-1.60(\mathrm{~m}, 2 \mathrm{H}), 1.48(\mathrm{~d}, J=7.0 \mathrm{~Hz}, 2 \mathrm{H})$. ${ }^{13} \mathrm{C}$ NMR (126 MHz, DMSO) $\delta 184.29,171.53,163.77,153.71,149.28,148.90,138.60,132.39$, $130.95,124.63,123.37,122.75,121.83,121.75,121.46,114.32,114.31,104.60,101.62,70.14$, 69.45, 36.70, 28.59, 25.52, 25.33. ESI-MS $\mathrm{C}_{25} \mathrm{H}_{24} \mathrm{BN}_{2} \mathrm{O}_{7}^{+}\left[\mathrm{M}+\mathrm{H}^{+}\right]$, found 475.1674, calculated 475.1674 .

BA-Resa. Yield: $160.3 \mathrm{mg}(69.4 \%) .{ }^{1} \mathrm{H}$ NMR (300 MHz, MeOD) $\delta 8.29-8.14$ (m, 2H), 7.85 (s, $1 \mathrm{H}), 7.70(\mathrm{t}, J=6.8 \mathrm{~Hz}, 1 \mathrm{H}), 7.39(\mathrm{~d}, J=7.2 \mathrm{~Hz}, 2 \mathrm{H}), 7.14(\mathrm{dd}, J=7.2,2.8 \mathrm{~Hz}, 2 \mathrm{H}), 6.87(\mathrm{dd}, J=$ 
10.0, $2.0 \mathrm{~Hz}, 1 \mathrm{H}), 6.39$ (t, $J=4.8 \mathrm{~Hz}, 1 \mathrm{H}), 4.29(\mathrm{q}, J=6.0 \mathrm{~Hz}, 2 \mathrm{H}), 2.51$ (q, $J=7.5 \mathrm{~Hz}, 2 \mathrm{H}), 2.08-$ $1.95(\mathrm{~m}, 2 \mathrm{H}), 1.89(\mathrm{dd}, J=15.1,7.5 \mathrm{~Hz}, 2 \mathrm{H}), 1.78-1.62(\mathrm{~m}, 2 \mathrm{H}) .{ }^{13} \mathrm{C} \mathrm{NMR}(75 \mathrm{MHz}, \mathrm{MeOD}) \delta$ 183.89 , 171.45, 163.10, 152.62, 147.90, 129.53, 128.83, 126.22, 126.04, 123.94, 123.26, 121.55, $120.56,119.90,119.75,112.97,104.90,102.51$, 99.24, 67.52, 34.84, 26.73, 23.60, 23.51. ESI-MS $\mathrm{C}_{24} \mathrm{H}_{23} \mathrm{BN}_{2} \mathrm{O}_{7} \mathrm{Na}^{+}\left[\mathrm{M}+\mathrm{H}^{+}\right]$, found 485.1496, calculated 485.1491.

Con-Resa. Yield: $143.7 \mathrm{mg}(68.8 \%) .{ }^{1} \mathrm{H}$ NMR (300 MHz, DMSO- $\left.d_{6}\right) \delta 8.15-7.94(\mathrm{~m}, 2 \mathrm{H}), 7.59$ $(\mathrm{dd}, J=8.3,1.3 \mathrm{~Hz}, 2 \mathrm{H}), 7.28(\mathrm{t}, J=7.8 \mathrm{~Hz}, 2 \mathrm{H}), 7.20(\mathrm{~d}, J=2.6 \mathrm{~Hz}, 1 \mathrm{H}), 7.12-6.96(\mathrm{~m}, 2 \mathrm{H}), 6.68$ $(\mathrm{dd}, J=10.0,1.9 \mathrm{~Hz}, 1 \mathrm{H}), 4.18(\mathrm{t}, J=6.4 \mathrm{~Hz}, 2 \mathrm{H}), 2.35(\mathrm{t}, J=7.3 \mathrm{~Hz}, 2 \mathrm{H}), 1.81$ (p, $J=6.6 \mathrm{~Hz}, 2 \mathrm{H})$, 1.69 (p, $J=7.3 \mathrm{~Hz}, 2 \mathrm{H}), 1.48(\mathrm{t}, J=6.7 \mathrm{~Hz}, 2 \mathrm{H}) .{ }^{13} \mathrm{C}$ NMR $(75 \mathrm{MHz}, \mathrm{DMSO}) \delta 183.80,171.09$, $163.28,153.24,148.80,139.28,131.89,130.47,128.57,124.16,122.89,121.26,119.01,118.91$, $113.83,112.53,104.10,101.14,68.95,36.25,28.08,25.01,24.75$. ESI-MS $\mathrm{C}_{24} \mathrm{H}_{22} \mathrm{~N}_{2} \mathrm{O}_{5} \mathrm{Na}^{+}[\mathrm{M}+$ $\left.\mathrm{H}^{+}\right]$, found 441.1423 , calculated 441.1421 .

Preparation of BA-Resa-P. BA-Resa $(20 \mathrm{mg}, 0.04 \mathrm{mmole})$ and reduced nicotinamide adenine dinucleotide (26 mg, 0.04 mmole) were dissolved in $10 \mathrm{~mL}$ DMSO/PBS buffer (v/v, 10/90, pH 9.5). After stirring for $30 \mathrm{~min}$ at $37^{\circ} \mathrm{C}, 20 \mathrm{~mL}$ DCM was added and extracted with water $(3 \mathrm{x} 50 \mathrm{~mL})$. The organic phase was collected and removed under vacuum. The product was purified by preparative TLC with a solvent system $(\mathrm{CH} 2 \mathrm{Cl} 2: \mathrm{MeOH}=100: 6)$. Yield: $8.9 \mathrm{mg}(50 \%)$. ${ }^{1} \mathrm{H}$ NMR $\left(300 \mathrm{MHz}, \mathrm{DMSO}-d_{6}\right) \delta 7.94(\mathrm{~s}, 1 \mathrm{H}), 7.87-7.76(\mathrm{~m}, 1 \mathrm{H}), 7.74-7.58(\mathrm{~m}, 2 \mathrm{H}), 7.49-7.40(\mathrm{~m}, 1 \mathrm{H})$, $7.30-7.12(\mathrm{~m}, 1 \mathrm{H}), 7.10-6.90(\mathrm{~m}, 2 \mathrm{H}), 6.72(\mathrm{dd}, J=9.7,2.1 \mathrm{~Hz}, 1 \mathrm{H}), 6.19(\mathrm{~s}, 1 \mathrm{H}), 4.08(\mathrm{t}, J=6.4$ $\mathrm{Hz}, 2 \mathrm{H}), 2.30(\mathrm{t}, J=7.2 \mathrm{~Hz}, 2 \mathrm{H}), 1.73(\mathrm{~d}, J=7.2 \mathrm{~Hz}, 2 \mathrm{H}), 1.62(\mathrm{q}, J=7.9,7.4 \mathrm{~Hz}, 2 \mathrm{H}), 1.49-1.35$ (m, 2H). ${ }^{13} \mathrm{C}$ NMR (75 MHz, DMSO) $\delta 185.11,170.89,162.66,149.52,145.12,144.82,138.33$, $134.71,133.49,131.15,128.67,128.67,127.65,127.45,125.06,121.03,113.95,105.49$, 100.55, 68.64, 36.14, 28.09, 24.98, 24.78. ESI-MS $\mathrm{C}_{24} \mathrm{H}_{22} \mathrm{BN}_{2} \mathrm{O}_{6} \mathrm{Na}^{+}\left[\mathrm{M}+\mathrm{H}^{+}\right]$, found 469.1559, calculated 469.1546.

\section{Photophysical Studies}

Measurement of photophysical properties. In general, the UV-Vis absorption and emission spectra were obtained on a Spectra Max M2 from Molecular Device. The excitation/emission slit width is $1 \mathrm{~nm}$ and the scan speed is medium. Stock solutions of the probes in DMSO (10 mM) were used to prepare the working solutions in buffered (PBS, $\mathrm{pH} 7.4$ or 9.5) DMSO/water (v/v, 50/50 or 
1/99) solution with a final concentration shown in Figure legend. Absorbance spectra were recorded from 350-700 nm while the emission spectra from 530-750 nm. $200 \mu \mathrm{L}$ buffer solution each well was used in the 96-well plates. The work temperature is $310 \mathrm{~K}$. The quantum yield was measured according the reported method and resazurin in PBS buffer ( $\mathrm{pH} \mathrm{9.5)} \mathrm{was} \mathrm{chosen} \mathrm{as} \mathrm{the} \mathrm{reference}$ fluorophore. ${ }^{1}$

\section{In Vitro Fluorescence Microscopic Studies}

Cell culture. Oral squamous cell carcinoma cell lines OSCC cells (American Type Culture Collection) were cultured as mono-layers in $75-\mathrm{cm}^{2}$ flasks with growth media containing DMEM (BSF) supplemented with $10 \%$ FBS (PAA), $1 \%$ penicillin streptomycin glutamine (GIBCO) at $37^{\circ} \mathrm{C}$ in a humidified incubator of $5 \% \mathrm{CO}_{2}$. Cells were carefully harvested and split when they reached $80 \%$ confluence to maintain exponential growth.

Cell cytotoxicity in MTT assay. OSCC cells were plated in 96-well flat-bottomed plates at $1 \times 10^{5}$ cells per well respectively and allowed to grow 6 or $24 \mathrm{~h}$ prior to exposure to the various concentrations of RA-Resa. Then MTT reagent was added for $4 \mathrm{~h}$ at $37^{\circ} \mathrm{C}$ and DMSO $(100 \mu \mathrm{L} / \mathrm{well})$ was further incubated with cells for $15 \mathrm{~min}$ after removing the medium. The absorbance at $570 \mathrm{~nm}$ and $690 \mathrm{~nm}$ (background signal) was recorded in a Spectra Max M2 microplate reader. The following formula was used to calculate the viability of cell growth: Cell viability $(\%)=($ mean of A value of treatment group / mean of A value of control) $\times 100$. The untreated group was used as control group. Each concentration was tested with 6 wells and the experiment was repeated 3 times.

Fluorescence microscopic imaging. To avoid the artifacts that occur during fixation procedures, all the experiments were conducted in live cells. There are five groups in the cell experiment. Before treatment, the culture medium was replaced by the medium/PBS solution (5/95, pH 7.4). In the first group (A), live cells (OSCC cells or CHO cells or Hela cells) were treated with $5 \mu \mathrm{M}$ RA-Resa for $15 \mathrm{~min}$ after incubation in the absence of glucose for $30 \mathrm{~min}$. In the group B and C, live cells were incubated with $1 \mathrm{mM}$ or $20 \mathrm{mM}$ glucose for $0.5 \mathrm{~h}$ respectively and further treated with $5 \mu \mathrm{M}$ RAResa for 15 min prior to imaging. In the fourth and fifth groups, live cells were cultured with $5 \mu \mathrm{M}$ RA-Resa for $15 \mathrm{~min}$ after incubation with $10 \mathrm{mM}$ lactate or $10 \mathrm{mM}$ lactate and $5 \mathrm{mM}$ pyruvate for $10 \mathrm{~min}$. The background signal was removed by the software Nikon Analysis and the fluorescence intensity was ranged from 6000 to 16000 . 


\section{Confocal microscopic imaging determining the subcellular location of probes.}

OSCC cells stained with $5 \mu \mathrm{M}$ RA-Resa and one of organelle markers for nucleus (Hoechst33342, 1 $\mu \mathrm{g} / \mathrm{ml}$ ), mitochondria (MitoTracker ${ }^{\circledR}$ Deep Red FM, $100 \mathrm{nM}$ ), lysosome (LysoTracker ${ }^{\circledR}$ Red DND99, $50 \mathrm{nM}$ ) or ER (ER-TrackerTM Red, $100 \mathrm{nM}$ ) for 30 min under HBSS solution containing 10 $\mathrm{mM}$ glucose. Golgi (BODIPY FL C5 ceramide, $1 \mu \mathrm{M}$ ) stain were carried under 4oC for $1 \mathrm{hr}$ prior to the staining of RA-Resa. Confocal images were acquired in 512x512 resolution using A1R+si Laser scanning confocal microscope (Nikon) with 60x objective (3x zoom) under 37oC supplemented with $5 \% \mathrm{CO} 2$.

\section{Supplemental Spectra}



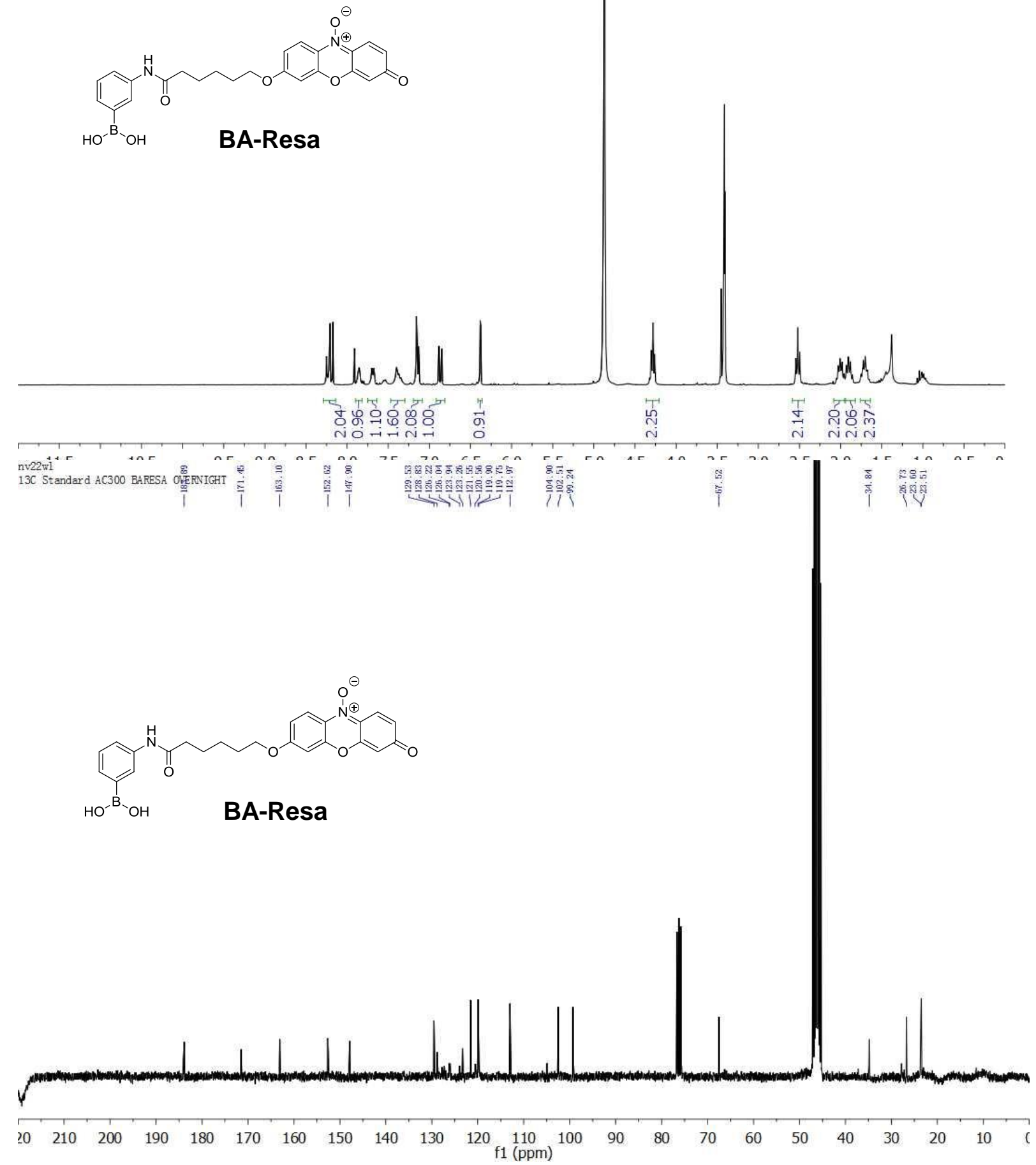


\begin{tabular}{|c|c|c|c|c|c|}
\hline \multicolumn{6}{|c|}{ Acquisition Parameter } \\
\hline Source Type & ESI & Ion Polarity & Positive & Set Nebulizer & $2.0 \mathrm{Bar}$ \\
\hline Focus & Not active & Set Capillary & $4500 \mathrm{~V}$ & Set Dry Heater & $200^{\circ} \mathrm{C}$ \\
\hline Scan Begin & $50 \mathrm{~m} / \mathrm{z}$ & Set End Plate Offset & $-500 \mathrm{~V}$ & Set Dry Gas & $6.0 \mathrm{~V} / \mathrm{min}$ \\
\hline Scan End & $2500 \mathrm{~m} / \mathrm{z}$ & Set Collision Cell RF & $300.0 \mathrm{Vpp}$ & Set Divert Valve & Waste \\
\hline $\begin{array}{l}\mathrm{m} / \mathrm{z} \\
1496\end{array}$ & Formula & $\mathrm{m} / \mathrm{z}$ err [ & $\mathrm{e}^{-}$Conf & & \\
\hline
\end{tabular}

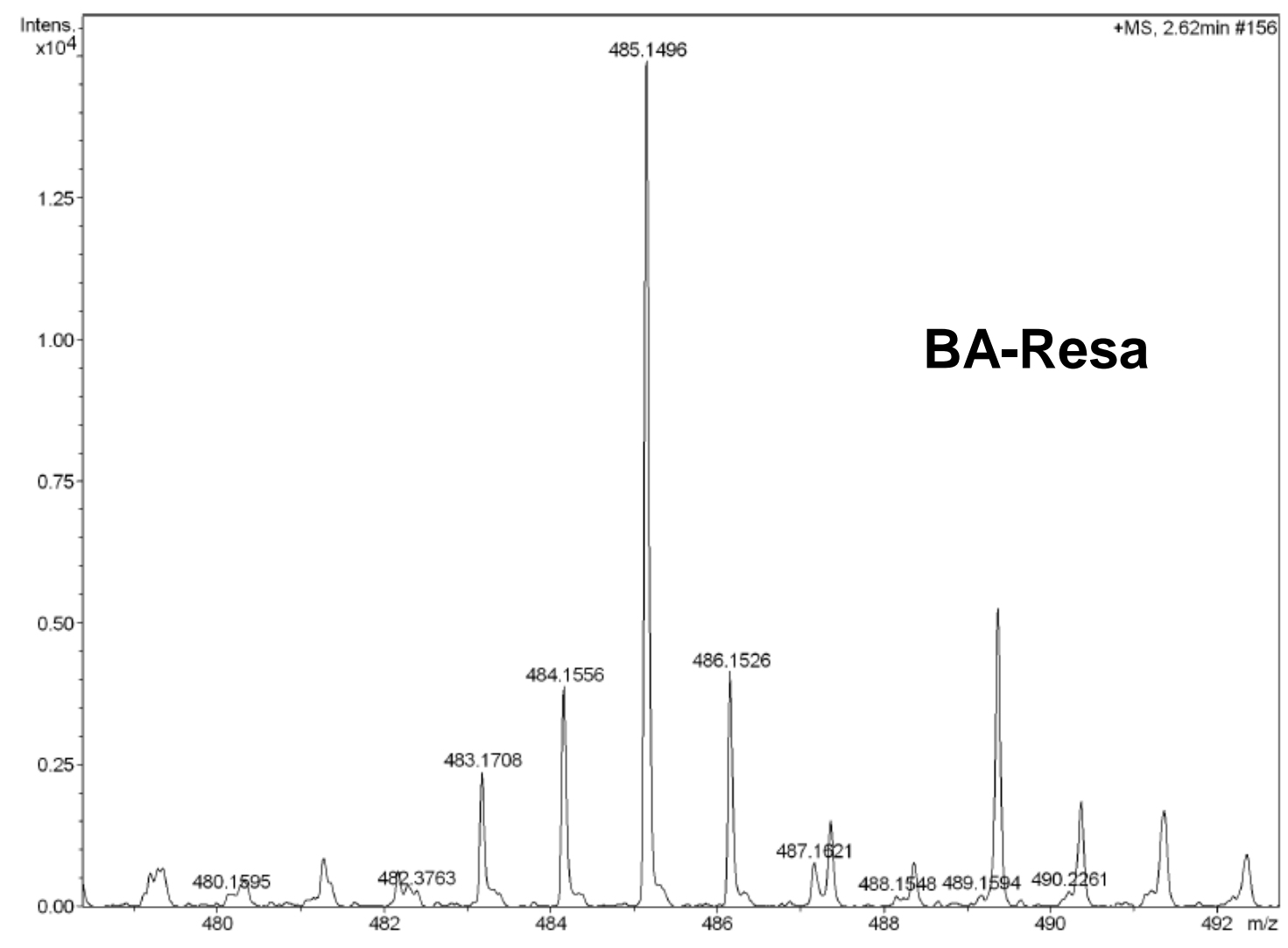



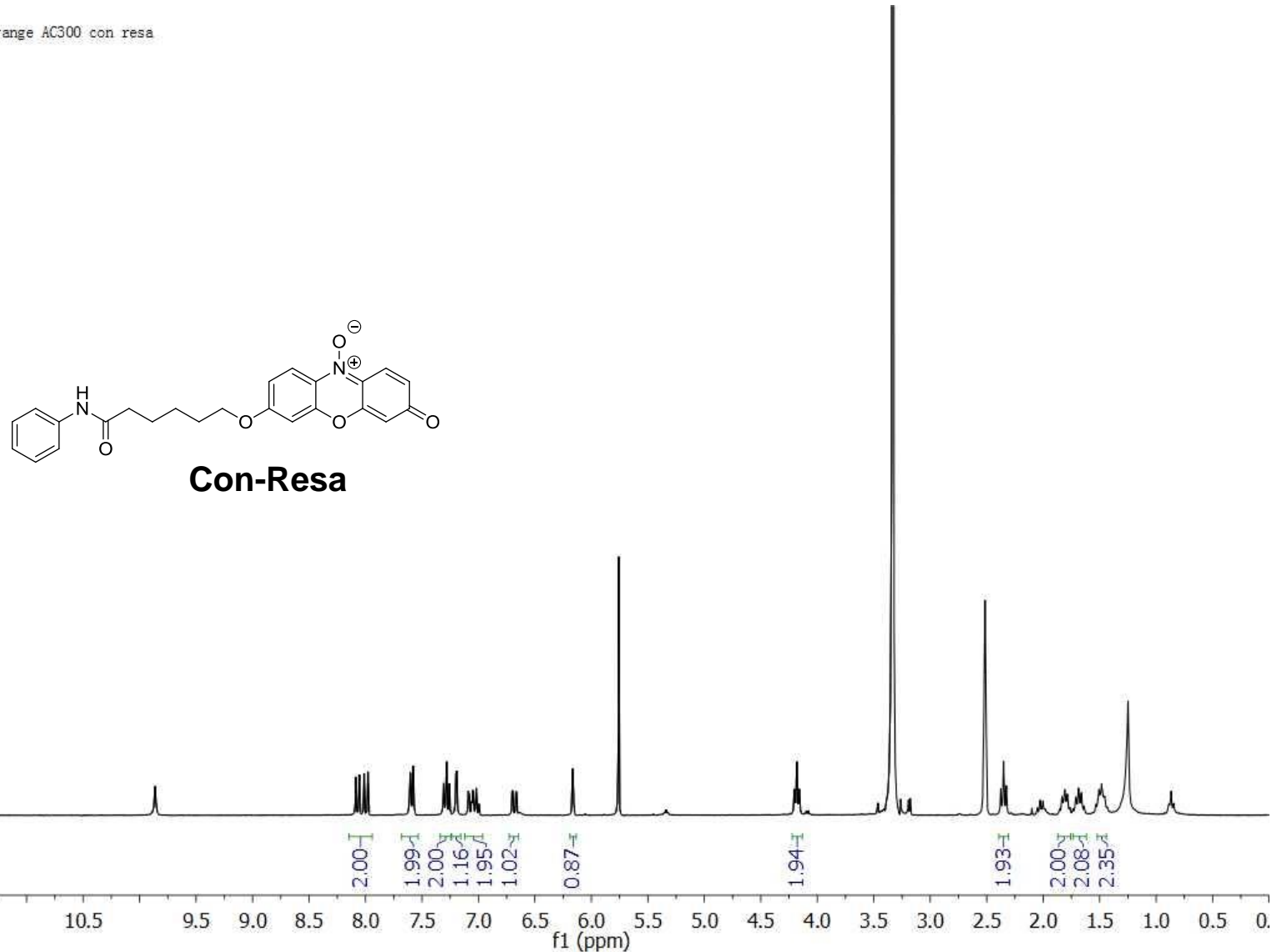
nv30w1
$13 C$ Standard AC300 con resa

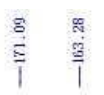

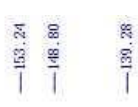

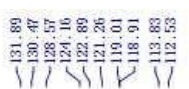

$\frac{1}{1}$
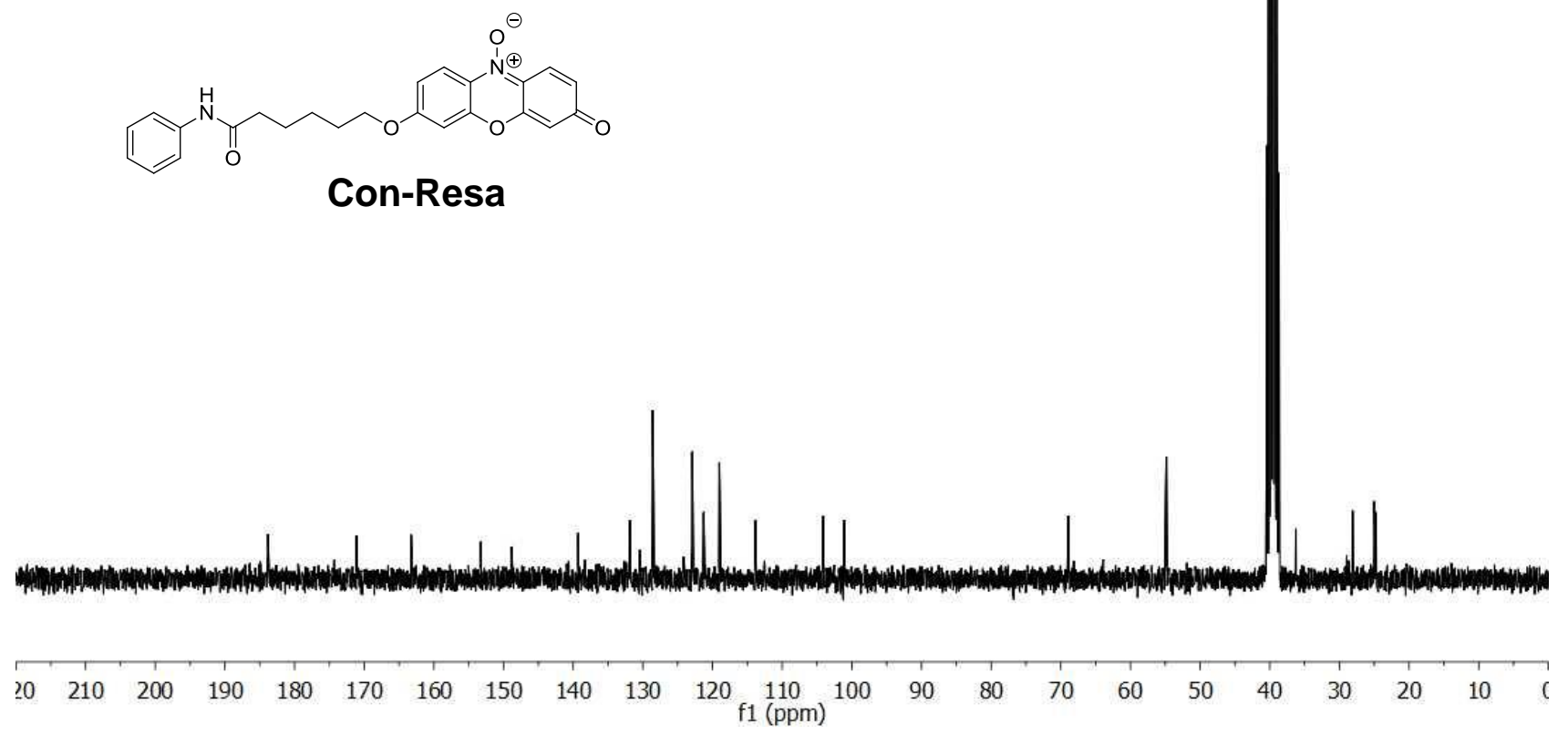

S27 
Acquisition Parameter

Source Type ESI

Focus

Scan Begin

Not active

$50 \mathrm{~m} / \mathrm{z}$

$2500 \mathrm{~m} / \mathrm{z}$

Scan End

Meas. $\mathrm{m} / \mathrm{z}$ \# Formula

$441.14231 \mathrm{C} 24 \mathrm{H} 22 \mathrm{~N} 2 \mathrm{NaO} 5$

Ion Polarity

$4500 \mathrm{~V}$

Set Nebulizer

Set Dry Heater

Set Dry Gas

Set Divert Valve

$\mathrm{m} / \mathrm{z}$ err [ppm] rdb e $\mathrm{e}^{-}$Conf $\mathrm{N}$-Rule
2.0 Bar

$200^{\circ} \mathrm{C}$ Waste

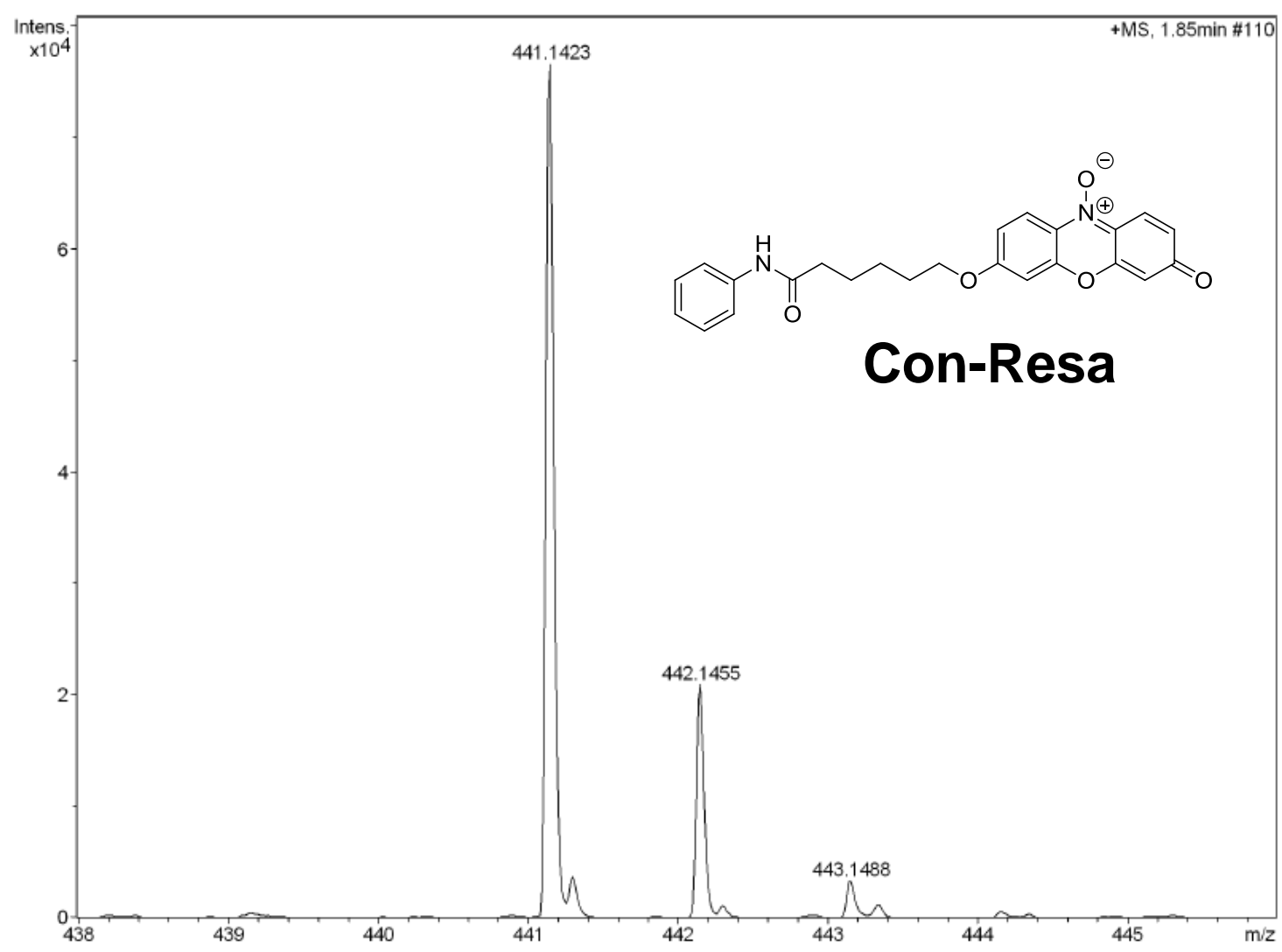



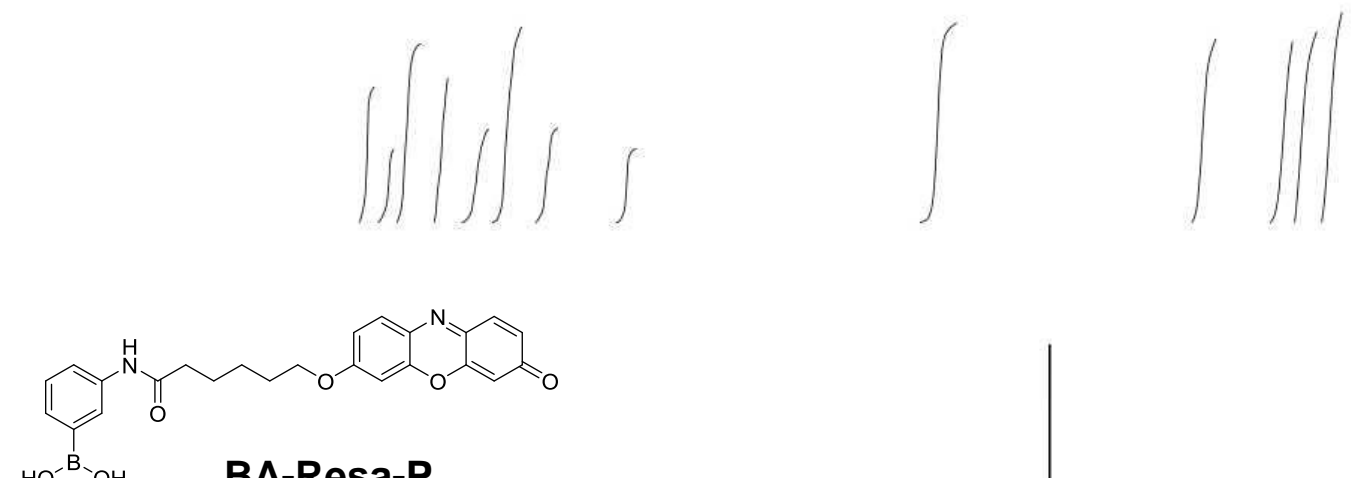

$\mathrm{HO}^{-\mathrm{B}} \mathrm{OH}^{-B}$ BA-Resa-P

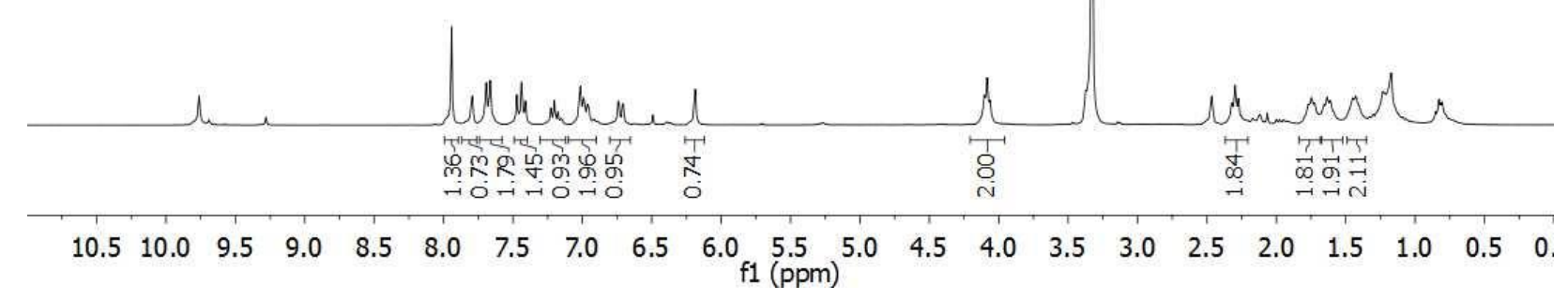

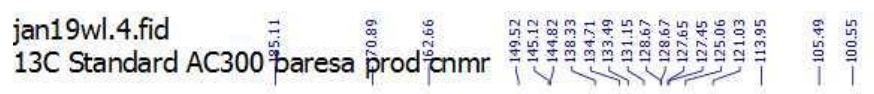
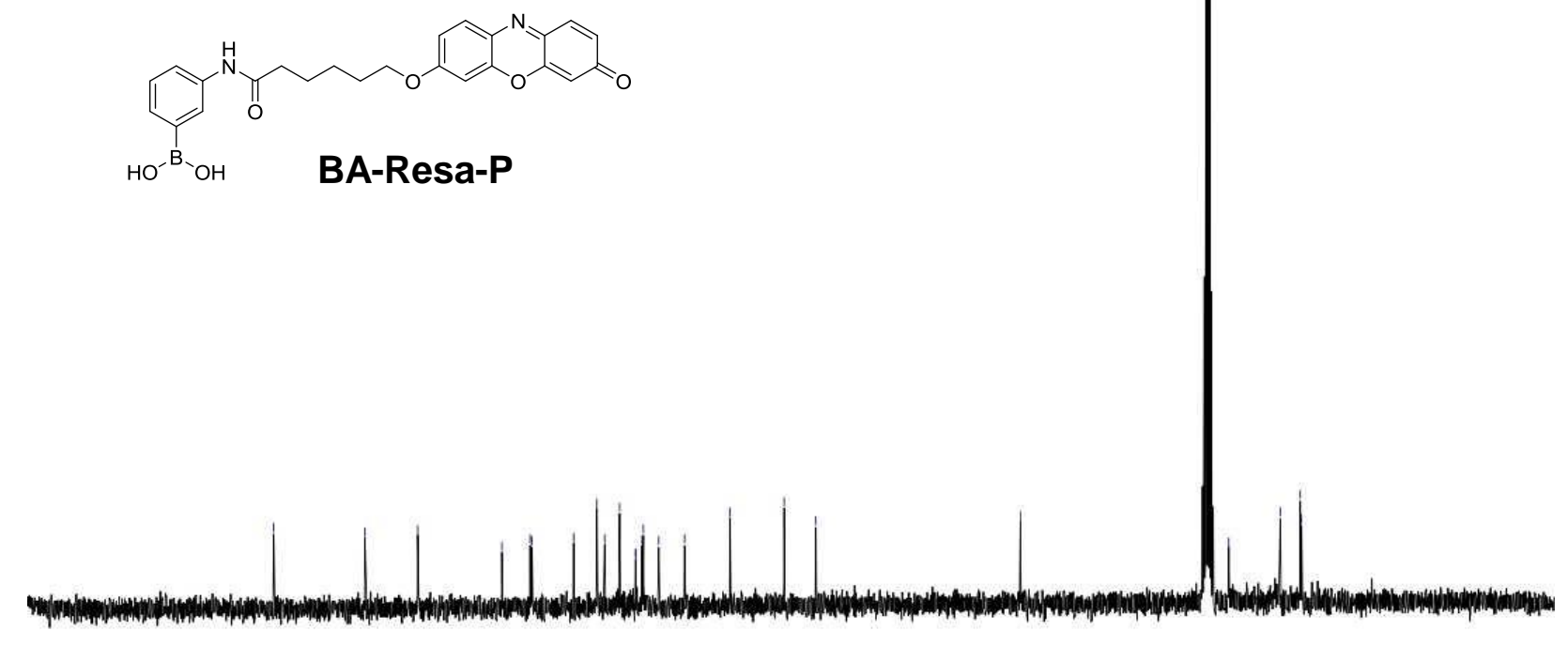

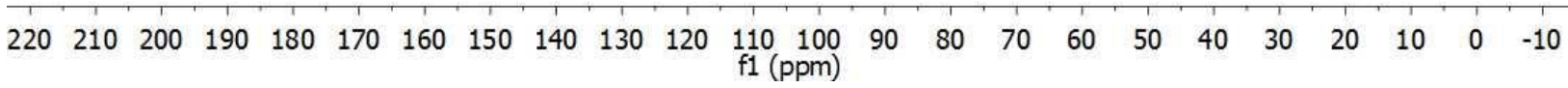


Acquisition Parameter

Source Type

Focus

ESI

Scan Begin

Scan End

$50 \mathrm{~m} / \mathrm{z}$

Ion Polarity

Set End Plate Offset

Set Collision Cell RF

Set Nebulizer

Set Dry Gas

$1800 \mathrm{~m} / \mathrm{z}$

Set Divert Valve

$6.0 \mathrm{l} / \mathrm{min}$

Meas. $\mathrm{m} / \mathrm{z}$ \# Formula

$\mathrm{m} / \mathrm{z}$ err $[\mathrm{ppm}] \quad$ rdb $\mathrm{e}^{-}$Conf $\quad \mathrm{N}-$ Rule

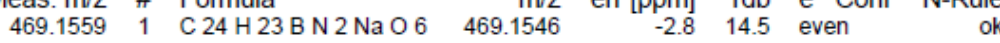

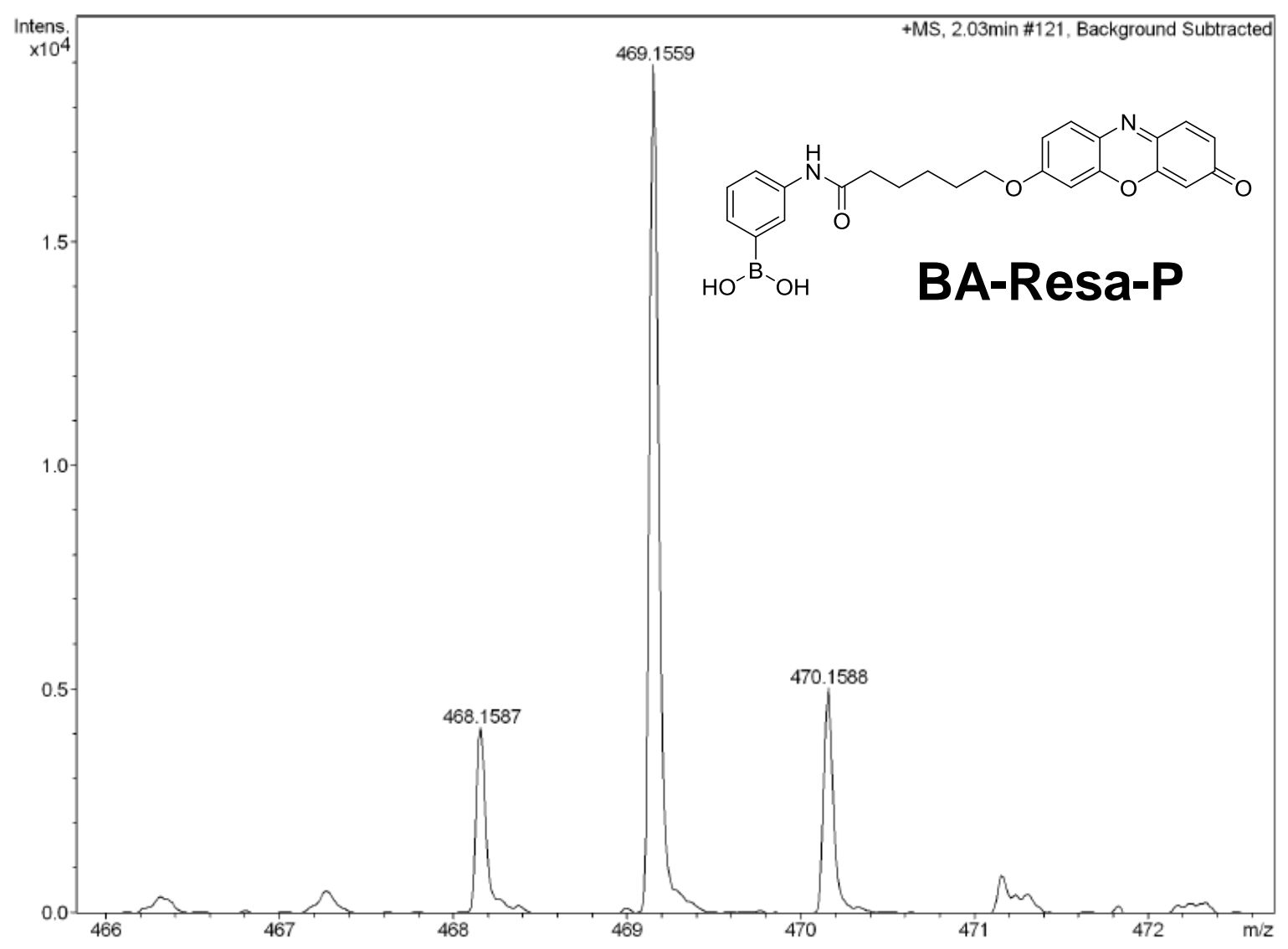




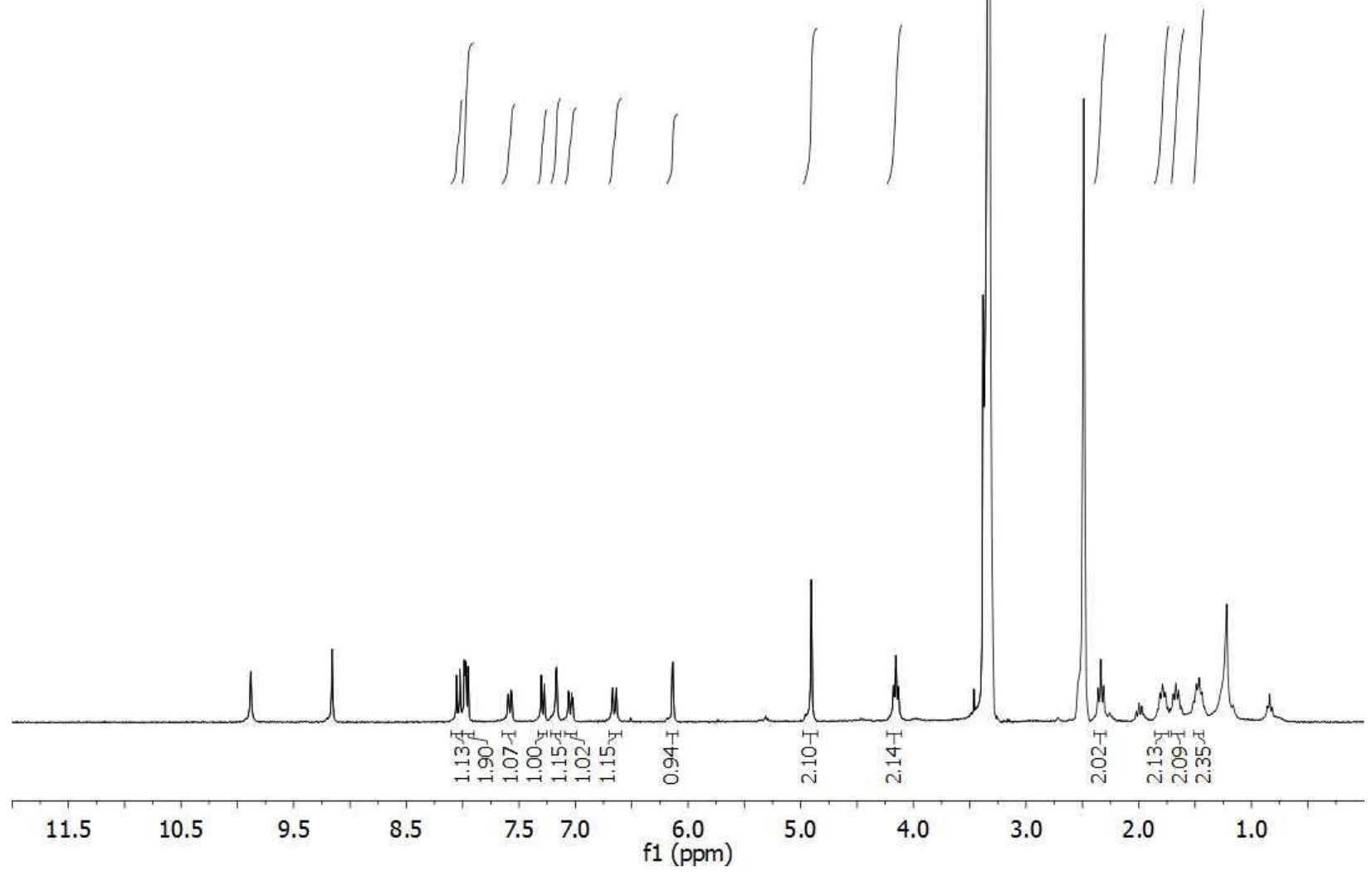

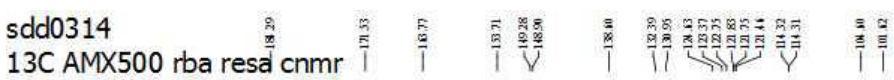

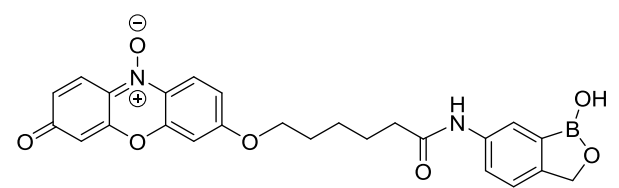

RA-Resa

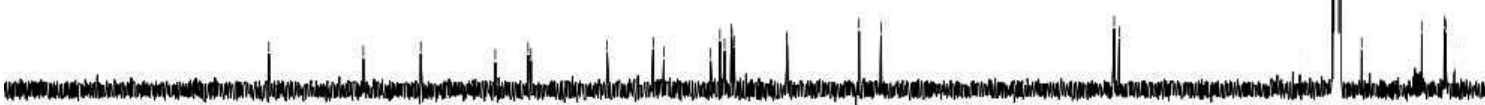

$\begin{array}{llllllllllllllll}210 & 190 & 170 & 150 & 130 & \begin{array}{c}110 \\ \mathrm{f}(\mathrm{ppm})\end{array} & 90 & 80 & 70 & 60 & 50 & 40 & 30 & 20 & 10 & (\end{array}$




\begin{tabular}{|c|c|c|c|c|c|}
\hline \multicolumn{6}{|c|}{ Acquisition Parameter } \\
\hline Source Type & ESI & Ion Polarity & Positive & Set Nebulizer & 2.0 Bar \\
\hline Focus & Not active & Set Capillary & $4500 \mathrm{~V}$ & Set Dry Heater & $200^{\circ} \mathrm{C}$ \\
\hline Scan Begin & $50 \mathrm{~m} / \mathrm{z}$ & Set End Plate Offset & $-500 \mathrm{~V}$ & Set Dry Gas & $6.0 \mathrm{l} / \mathrm{min}$ \\
\hline Scan End & $1800 \mathrm{~m} / \mathrm{z}$ & Set Collision Cell RF & $200.0 \mathrm{Vpp}$ & Set Divert Valve & Waste \\
\hline
\end{tabular}

$\begin{array}{rrrrrr}475.1674 & 1 & \mathrm{C} 25 \mathrm{H} 24 \mathrm{BN} 207 & 475.1675 & 0.3 & 15.5\end{array}$

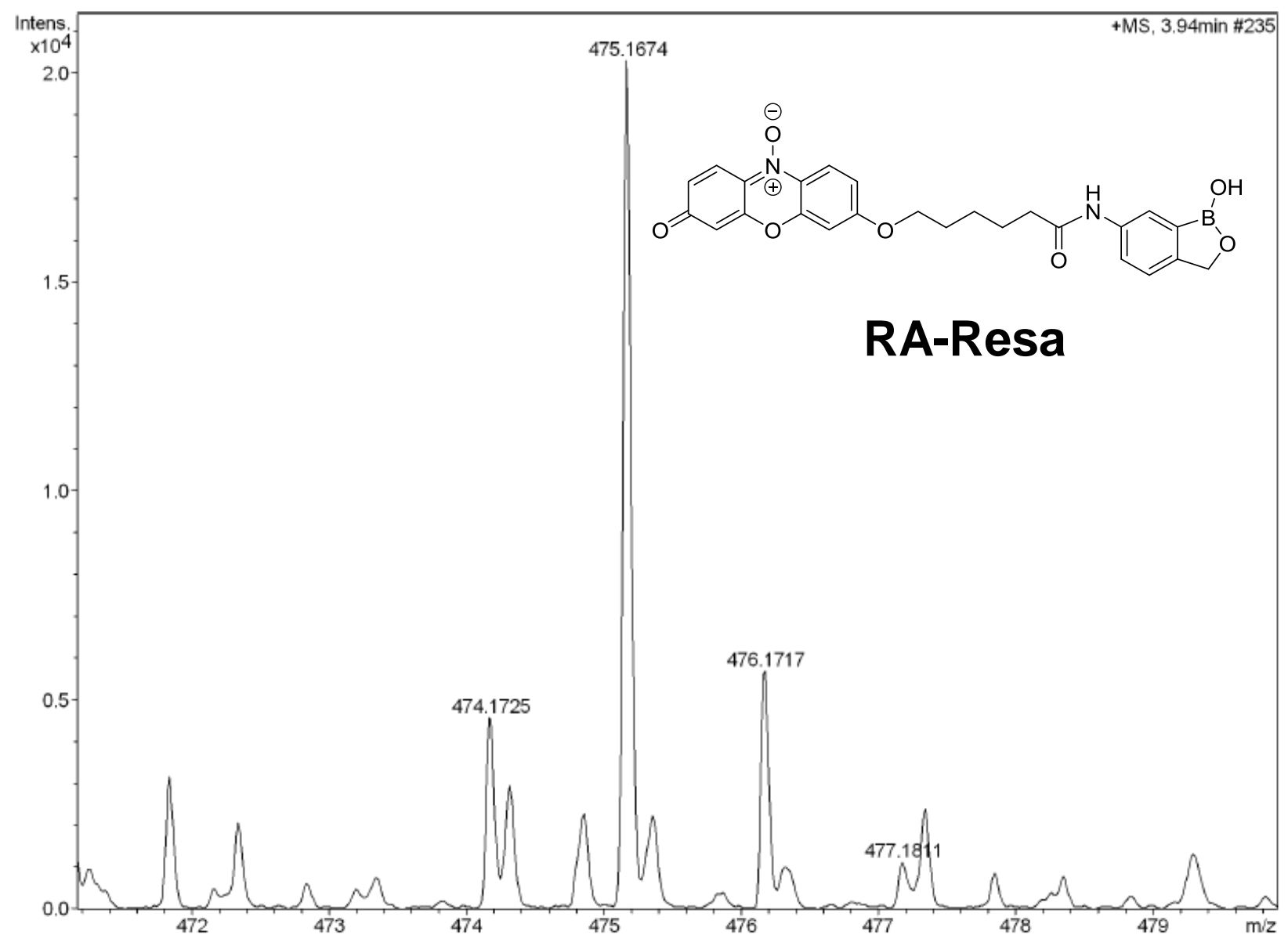




\section{Reference:}

(1) Bueno, C.; Villegas, M. L.; Bertolotti, S. G.; Previtali, C. M.; Neumann, M. G.; Encinas, M. V. Photochemistry and photobiology 2002, 76, 385.

(2) Yuan, L.; Lin, W.; Yang, Y. Chemical communications 2011, 47, 6275. 